\title{
Prophylaxis, diagnosis and therapy of infections in patients undergoing high-dose chemotherapy and autologous haematopoietic stem cell transplantation. 2020 update of the recommendations of the Infectious Diseases Working Party (AGIHO) of the German Society of Hematology and Medical Oncology (DGHO)
}

\author{
Maximilian Christopeit ${ }^{1}$ (D) Martin Schmidt-Hieber ${ }^{2} \cdot$ Rosanne Sprute $^{3,4,5} \cdot$ Dieter Buchheidt $^{6} \cdot$ Marcus Hentrich $^{7}$. \\ Meinolf Karthaus ${ }^{8}$ - Olaf Penack ${ }^{9}$ - Markus Ruhnke ${ }^{10}$. Florian Weissinger ${ }^{11}$ - Oliver A. Cornely ${ }^{3,4,5,12}$. \\ Georg Maschmeyer ${ }^{13}$
}

Received: 6 July 2020 / Accepted: 3 October 2020 / Published online: 20 October 2020

(C) The Author(s) 2020

\begin{abstract}
To ensure the safety of high-dose chemotherapy and autologous stem cell transplantation (HDC/ASCT), evidence-based recommendations on infectious complications after HDC/ASCT are given. This guideline not only focuses on patients with haematological malignancies but also addresses the specifics of HDC/ASCT patients with solid tumours or autoimmune disorders. In addition to HBV and HCV, HEV screening is nowadays mandatory prior to ASCT. For patients with HBs antigen and/or anti-HBc antibody positivity, HBV nucleic acid testing is strongly recommended for 6 months after HDC/ASCT or for the duration of a respective maintenance therapy. Prevention of VZV reactivation by vaccination is strongly recommended. Cotrimoxazole for the prevention of Pneumocystis jirovecii is supported. Invasive fungal diseases are less frequent after HDC/ ASCT, therefore, primary systemic antifungal prophylaxis is not recommended. Data do not support a benefit of protective room ventilation e.g. HEPA filtration. Thus, AGIHO only supports this technique with marginal strength. Fluoroquinolone prophylaxis is recommended to prevent bacterial infections, although a survival advantage has not been demonstrated.
\end{abstract}

Maximilian Christopeit, Martin Schmidt-Hieber and Rosanne Sprute contributed equally to this work. Oliver A. Cornely and Georg Maschmeyer contributed equally to this work.

Maximilian Christopeit

Maximilian.Christopeit@med.uni-tuebingen.de

1 Department of Stem Cell Transplantation, University Medical Center Eppendorf, Hamburg, Germany

2 Department of Hematology and Oncology, Carl-Thiem-Klinikum, Cottbus, Cottbus, Germany

3 Cologne Excellence Cluster on Cellular Stress Responses in Aging-Associated Diseases (CECAD), University of Cologne, Cologne, Germany

4 Department I of Internal Medicine, University Hospital of Cologne, University of Cologne, Cologne, Germany

5 Partner Site Bonn-Cologne, German Centre for Infection Research, Cologne, Germany

6 Department of Hematology and Oncology, Mannheim University Hospital, Heidelberg University, Mannheim, Germany
7 Department of Medicine III-Hematology/Oncology, Red Cross Hospital, Munich, Germany

8 Department of Internal Medicine, Hematology and Oncology, Klinikum Neuperlach, Städtisches Klinikum München, Munich, Germany

9 Department of Internal Medicine, Division of Hematology and Oncology, Charité Universitätsmedizin Berlin, Campus Rudolf Virchow, Berlin, Germany

10 Department of Hematology, Oncology and Palliative Medicine, Helios Hospital Aue, Aue, Germany

11 Department of Internal Medicine, Hematology, Oncology, Stem Cell Transplantation and Palliative Medicine, Protestant Hospital of Bethel Foundation, Bielefeld, Germany

12 Clinical Trials Centre Cologne (ZKS Köln), University of Cologne, Cologne, Germany

13 Klinikum Ernst von Bergmann, Department of Hematology, Oncology and Palliative Care, Potsdam, Germany 
Keywords Autologous stem cell transplantation · Infection

\section{Introduction}

High-dose chemotherapy (HDC) and autologous stem cell transplantation (ASCT) constitute a standard of care in the treatment of heamatologic malignancies, in particular, multiple myeloma [1], malignant lymphoma [2, 3] and acute myeloid leukaemia [4]. HDC and ASCT are also used in solid tumours such as neuroblastoma, sarcoma, germinal tumours [5] and autoimmune diseases e.g. multiple sclerosis [6], systemic sclerosis [7] and Crohn's disease [8]. In total, the number of ASCT reported to the European Society for Blood and Marrow Transplantation in 2018 exceeds 27,750, including more than 560 for non-malignant disorders, mostly autoimmune diseases, and 1545 for solid tumours [9].

After HDC and ASCT, up to $90 \%$ of patients will experience infections, mostly presenting as fever of unknown origin (FUO) [10].

Due to indwelling venous catheters and toxicities of conditioning regimens, in particular, mucositis and gastrointestinal barrier impairment, both Gram-positive and Gramnegative bacteria may cause fever and infection after HDC/ ASCT [11]. Bacterial pneumonia, colitis and bloodstream infection (BSI), including catheter-related BSI, are the prevailing documented infections in patients after HDC/ASCT [11, 12]. Invasive fungal disease and viral infections, ranging from herpes to hepatitis viruses, may occur as well, extending into the period after transplantation $[13,14]$.

\section{Methods}

\section{Development of the guideline}

These recommendations on prophylaxis, diagnosis and treatment of infectious complications after HDC/ASCT by the Infectious Diseases Working Party (AGIHO) of the German Society of Haematology and Medical Oncology (DGHO) are the fourth edition after 1999, 2003 and 2012 [15-17]. The expert panel assessed the recommendations in a stepwise consensus process, consisting of telephone and video conferences. All members of the AGIHO were invited to the consensus meetings. The guideline was approved by the AGIHO assembly on May 7, 2020.

This guidance document is embedded into other AGIHO recommendations on infection management in patients with haematological and oncological diseases [18-25]. It provides an evaluation of current evidence and the consensus interpretation of the authors. Recommendations are not mandatory and intend to assist physicians in decisions on individual patients. We regard correct dosing to be a responsibility of the prescribing physicians and do not mention this in this guideline.

Strength of recommendation and quality of evidence were graded according to the criteria applied by the European Society for Clinical Microbiology and Infectious Diseases (ESCMID) and the European Confederation of Medical Mycology (ECMM; Table 1) [26, 27].
Table 1 Definitions of strength of recommendation and quality of evidence

\begin{tabular}{ll}
\hline $\begin{array}{l}\text { Category, } \\
\text { grade }\end{array}$ & Definition \\
\hline Strength of recommendation \\
A & AGIHO strongly supports a recommendation for use \\
B & AGIHO moderately supports a recommendation for use \\
C & AGIHO marginally supports a recommendation for use \\
D & AGIHO supports a recommendation against use \\
Quality of evidence \\
I & Evidence from at least 1 properly designed randomized, controlled trial \\
II & Evidence from at least 1 well-designed clinical trial, without randomization; from cohort or \\
& case-controlled analytic studies (preferably from > 1 centre); from multiple time series; or \\
& from dramatic results of uncontrolled experiments \\
IIr & meta-analysis or systematic review of RCT \\
IIt & transferred evidence, i.e. results from different patient cohorts or similar immune status \\
& situation \\
IIh & comparator group historical control \\
IIu & uncontrolled trials \\
IIa & published abstract, presented at an international symposium or meeting \\
III & Evidence from opinions of respected authorities, based on clinical experience, descriptive case \\
& studies \\
\hline
\end{tabular}




\section{Risk stratification}

Both depth and duration of neutropenia have been associated with the risk of cancer patients to develop an infection that will take a more severe and complicated course [28]. AGIHO regards patients with expected neutropenia $<500 / \mu \mathrm{l}$ for at least 8 days to be at high risk and those with an expected duration of neutropenia of up to 7 days at standard risk for the development of an infection with a complicated course [18]. While it is generally presumed that patients after HDC/ASCT are amongst those with neutropenia lasting for 8 days or longer, thus are at high risk for complicated infection, data from prospective clinical trials show that the duration of neutropenia may often be in the standard risk range after HDC/ ASCT [29]. However, profound, and sometimes longlasting defects of components of the adaptive immune system are observed besides neutropenia after HDC/ ASCT. Causes may lie in the nature of the underlying disease, timing and type of previous treatments, history of previous infection and specifics of the conditioning regimen e.g. nucleoside analogues or antilymphocyte globulins [6, 30-34]. In conclusion, AGIHO considers patients after HDC/ASCT at high risk for developing infections with a complicated course. Hereby, conditioning with carmustine, etoposide, cytarabine and melphalan (BEAM) prior to ASCT is associated with an increased risk for infections compared to conditioning with highdose melphalan [35].

\section{Diagnostic procedures before the onset of fever or infection}

Surveillance blood cultures in the absence of fever or other signs of infection are discouraged [36, 37]. Likewise, routine screening for invasive aspergillosis by serial determination of galactomannan antigen or 1,3- $\beta$-D-glucan is not recommended in these patients [38]. In individual patients at increased risk for invasive Aspergillus spp. infection, e.g. patients with previous aspergillosis who are without current systemic mould-active prophylaxis, twice-weekly galactomannan and/ or 1,3- $\beta$-D-glucan surveillance may be considered. For more detailed information, refer to the separate guideline on diagnosis of fungal infection [20].

Screening for hepatitis B virus (HBV; anti-HBc antibodies, $\mathrm{HBsAg}$, nucleic acid testing), hepatitis $\mathrm{C}$ virus (HCV; anti$\mathrm{HCV}$, nucleic acid testing), hepatitis $\mathrm{E}$ virus (HEV; nucleic acid testing) and human immunodeficiency virus (HIV; HIV1/2 antibodies, nucleic acid testing) is requested in all patients prior to release of the autologous graft [39, 40]. These screening tests should be repeated at least 30 days before HDC/ASCT. Monitoring of HBV viral load is strongly recommended in $\mathrm{HBsAg}$ and/or anti-HBc antibody positive patients for 6 months after HDC/ASCT, as immunosuppression can lead to viral reactivation and disease [41-45]. If maintenance therapy using rituximab, lenalidomide or bortezomib is administered, monitoring should be continued for 6 months following cessation of the respective maintenance therapy.

In patients with respiratory symptoms, screening for respiratory tract pathogens should include severe acute respiratory syndrome coronavirus 2 (SARS-CoV-2). HDC/ASCT may be deferred until the patient is asymptomatic [46, 47].

Diagnostic procedures recommended before onset of fever or infection are given in Table 2.

\section{Diagnostic procedures in case of fever or infection}

Thorough physical examination of a febrile neutropenic patient is mandatory. We strongly recommend two separate pairs of venous blood cultures in case of fever or other signs or symptoms of infection. In the presence of a central venous catheter (CVC), one of the two pairs should be obtained from the catheter. To increase the diagnostic yield of blood cultures, it is recommended with moderate strength to draw blood from each individual CVC lumen, or to obtain a third pair of blood cultures [48-50]. Determination of the differential time to positivity (DTTP) between blood cultures drawn from the CVC and a peripheral vein might be useful to identify the source of BSI [51]. DTTP of $2 \mathrm{~h}$ or more is suggestive of catheter-related BSI [52]. DTTP may be a useful tool to diagnose Candida spp. BSI, with a cut-off value of $6 \mathrm{~h}$ for Candida glabrata BSI and $2 \mathrm{~h}$ for other Candida spp. [53]. In contrast, DTTP has not proven useful in the diagnosis of Staphylococcus aureus BSI [54, 55]. In S. aureus or Candida spp. BSI CVC should be removed whenever possible, independent of the exact source of infection [24]. Chest X-rays are commonly discouraged to diagnose lung infection in tumour patients, since infiltrates are frequently invisible [56, 57]. High-resolution/multislice thoracic CT scan without contrast enhancement has a significantly higher sensitivity than chest X-ray and should be performed in patients with respiratory symptoms or persisting fever despite antimicrobial treatment over 72 96 h [22, 57]. Diagnostic bronchoscopy, bronchial or bronchoalveolar lavage for patients with pulmonary infiltrates (histology, cytology, culture, antigen testing, nucleic acid testing) should be applied whenever possible. Further diagnostics (e.g. abdominal or central nervous system imaging) might also be required, depending on symptoms, clinical signs and laboratory parameters. Signs of sepsis in the absence of fever as well as hypothermia should prompt diagnostic procedures as for a first fever, and empiric antibiotic treatment.

Diagnostic procedures recommended at onset of fever or infection are summarized in Table 3. 
Table 2 Diagnostic procedures before the onset of fever or infection in HDC/ASCT recipients

\begin{tabular}{|c|c|c|c|c|c|}
\hline Population & Intention & Intervention & SoR & QoE & References \\
\hline $\begin{array}{l}\text { Prior to } \\
\text { HDC/ASCT }\end{array}$ & $\begin{array}{l}\text { To detect } \mathrm{HBV}, \mathrm{HCV}, \mathrm{HEV}, \mathrm{HIV} \text {, and } \mathrm{HDV} \text { status before } \\
\text { release of autologous graft and and } \leq 30 \text { days before } \\
\text { HDC/ASCT }\end{array}$ & $\begin{array}{l}\text { Screening for } \\
\text { - HBV (anti-HBc } \\
\text { antibodies, HBs antigen, } \\
\text { nucleic acid testing) } \\
\text { - HCV (anti-HCV, nucleic } \\
\text { acid testing) } \\
\text { - HEV (nucleic acid testing) } \\
\text { - HIV (HIV } 1 / 2 \text { antibodies, } \\
\text { nucleic acid testing) } \\
\text { - Anti-delta if HBsAg posi- } \\
\text { tive }\end{array}$ & A & III & $\begin{array}{l}\text { RiliBÄK Dtsch } \\
\quad \text { Arztebl (2019) [40] }\end{array}$ \\
\hline $\begin{array}{l}\mathrm{HBsAg} \text { and/or } \\
\text { anti-HBc posi- } \\
\text { tive }\end{array}$ & To detect viral reactivation & $\begin{array}{l}\text { HBV nucleic acid testing } \\
\text { for } \geq 6 \text { months after } \\
\text { HDC/ASCT }\end{array}$ & A & IIu & $\begin{array}{l}\text { Jun Hepatol Int (2017) } \\
\text { [42] } \\
\text { Kusumoto CID (2015) } \\
\text { [44] }\end{array}$ \\
\hline $\begin{array}{l}\text { Unexplained } \\
\text { elevated liver } \\
\text { function tests }\end{array}$ & To detect viremia prior to $\mathrm{HDC} / \mathrm{ASCT}$ & HEV nucleic acid testing & B & IIt & $\begin{array}{l}\text { Von Felden J Hepatol } \\
\quad(2019)[100] \\
\text { Furfaro BBMT (2020) } \\
\text { [101] }\end{array}$ \\
\hline CMV-seropositive & $\begin{array}{l}\text { To detect CMV viremia and reduce CMV disease and } \\
\text { CMV-related mortality }\end{array}$ & $\begin{array}{l}\text { Routine screening for CMV } \\
\text { viremia (CMV-PCR) }\end{array}$ & $\mathrm{D}$ & IIu & $\begin{array}{l}\text { Marchesi } \\
\text { Hematol Oncol } \\
(2018) \text { [102] } \\
\text { Kaya Transpl Proc } \\
\quad \text { (2017) [103] } \\
\text { Massoud JCV (2017) } \\
\text { [104] } \\
\text { Piukovisc } \\
\text { Ann Hematol } \\
\text { (2017) [105] }\end{array}$ \\
\hline HSV-seropositive & To detect HSV viremia and reduce HSV-related mortality & $\begin{array}{l}\text { Routine screening for HSV } \\
\text { viremia (HSV-PCR) }\end{array}$ & $\mathrm{D}$ & IIu & $\begin{array}{l}\text { Inazawa JMV (2017) } \\
\text { [76] }\end{array}$ \\
\hline VZV-seropositive & To detect VZV viremia and reduce VZV-related mortality & $\begin{array}{l}\text { Routine screening for VZV } \\
\text { viremia (VZV-PCR) }\end{array}$ & $\mathrm{D}$ & III & No reference \\
\hline Any & To reduce mortality and incidence of PTLD & $\begin{array}{l}\text { Routine screening for EBV } \\
\text { viremia (EBV-PCR) }\end{array}$ & $\mathrm{D}$ & IIu & $\begin{array}{l}\text { Mehra CID (2019) } \\
\text { [77] } \\
\text { Inazawa JMV (2017) } \\
\quad[76] \\
\text { Chiusolo JCI (2010) } \\
\quad[106]\end{array}$ \\
\hline Any & $\begin{array}{l}\text { To reduce the incidence of HHV- } 6 \text { disease and } \\
\text { infection-related mortality }\end{array}$ & $\begin{array}{l}\text { Routine screening for } \\
\text { HHV-6 (HHV-6-PCR) }\end{array}$ & $\mathrm{D}$ & IIu & $\begin{array}{l}\text { Balsat J Infect (2019) } \\
\text { [75] } \\
\text { Inazawa JMV (2017) } \\
\text { [76] } \\
\text { Piukovics In Vivo } \\
\text { (2014) [107] }\end{array}$ \\
\hline $\begin{array}{l}\text { Afebrile, } \\
\text { neutropenic }\end{array}$ & $\begin{array}{l}\text { To diagnose blood stream infection with the aim to reduce } \\
\text { infection related mortality }\end{array}$ & Surveillance blood cultures & $\mathrm{D}$ & $\mathrm{IIu}$ & $\begin{array}{l}\text { Ghazal Antimicrob } \\
\text { Resist Infect Control } \\
\text { (2014) [36] }\end{array}$ \\
\hline $\begin{array}{l}\text { Afebrile, } \\
\text { neutropenic }\end{array}$ & To diagnose invasive aspergillosis & $\begin{array}{l}\text { Surveillance serum } \\
\text { galactomannan antigen }\end{array}$ & $\mathrm{D}$ & IItu & $\begin{array}{l}\text { Duarte CID (2014) } \\
\quad[108]\end{array}$ \\
\hline $\begin{array}{l}\text { Afebrile, } \\
\text { neutropenic }\end{array}$ & To diagnose invasive aspergillosis & $\begin{array}{l}\text { Surveillance serum } \\
1,3-\beta \text {-D-glucan }\end{array}$ & $\mathrm{D}$ & IIt & $\begin{array}{l}\text { Hammerström } \\
\text { EJCMID (2015) } \\
\text { [109] } \\
\text { Cornely JAC (2017) } \\
\text { [110] }\end{array}$ \\
\hline
\end{tabular}




\section{Antimicrobial prophylaxis for patients during and after HDC/ASCT}

\section{Antibacterial prophylaxis}

Prophylactic antimicrobial use can be considered in ASCT recipients during pre-engraftment when the duration of profound neutropenia (absolute neutrophil count $<100 / \mu \mathrm{l}$ ) is expected to be at least 7 days. One placebo-controlled randomized trial has shown a reduction in the number of infections in patients, including those after HDC/ASCT, when using levofloxacin prophylaxis [58]. Moreover, a retrospective study with ASCT recipients has shown significant reduction of febrile neutropenia and BSI under prophylaxis with
Table 3 Diagnostic procedures in fever or infection in HDC/ASCT recipients

\begin{tabular}{|c|c|c|c|c|c|}
\hline Population & Intention & Intervention & SoR & QoE & References \\
\hline First fever & $\begin{array}{l}\text { To diagnose bloodstream } \\
\text { infection }\end{array}$ & $\begin{array}{l}\text { Analysis of two separate } \\
\text { pairs of venous blood } \\
\text { cultures }(2 \times \text { aerobic } / 2 \times \\
\text { anaerobic })\end{array}$ & $\mathrm{A}$ & $\mathrm{IIu}$ & $\begin{array}{l}\text { Lee JCM } \\
\quad(2007) \text { [48] } \\
\text { Cockerill CID } \\
\quad(2004) \text { [49] } \\
\text { Bouza CID } \\
\quad(2007)[111]\end{array}$ \\
\hline $\begin{array}{l}\text { Fever in } \\
\text { presence of } \\
\text { CVC }\end{array}$ & $\begin{array}{l}\text { To diagnose bloodstream } \\
\text { infection }\end{array}$ & $\begin{array}{l}\text { Analysis of two separate } \\
\text { pairs of venous blood } \\
\text { cultures }(2 \times \text { aerobic/ } 2 \times \\
\text { anaerobic), one of } \\
\text { which is drawn from the } \\
\text { catheter (total volume } \\
40 \mathrm{ml} \text { ) }\end{array}$ & $\mathrm{A}$ & IIu & $\begin{array}{l}\text { Lee JCM } \\
\quad(2007) \text { [48] } \\
\text { Cockerill CID } \\
\quad(2004) \text { [49] } \\
\text { Planes EIMC } \\
\quad(2016)[112]\end{array}$ \\
\hline $\begin{array}{l}\text { Fever in } \\
\text { presence of } \\
\text { CVC }\end{array}$ & $\begin{array}{l}\text { To increase diagnostic } \\
\text { yield of blood cultures }\end{array}$ & $\begin{array}{l}\text { Analysis of a blood sample } \\
\text { from each lumen of the } \\
\text { central venous catheter }\end{array}$ & $\mathrm{B}$ & IItu & $\begin{array}{l}\text { Guembe CID } \\
\quad(2010) \text { [50] } \\
\text { Herrera-Guerra } \\
\text { AJIC (2015) } \\
\text { [113] }\end{array}$ \\
\hline $\begin{array}{l}\text { Fever in } \\
\text { presence of } \\
\text { CVC }\end{array}$ & $\begin{array}{l}\text { To increase diagnostic } \\
\text { yield of blood cultures }\end{array}$ & $\begin{array}{l}\text { Analysis of a third pair of } \\
\text { blood cultures (total } \\
\text { volume } 60 \mathrm{ml} \text { ) }\end{array}$ & $\mathrm{B}$ & IItu & $\begin{array}{l}\text { Guembe CID } \\
\quad(2010)[50]\end{array}$ \\
\hline Fever & To diagnose pneumonia & $\begin{array}{l}\text { Chest X-ray in two pro- } \\
\text { jections }\end{array}$ & $\mathrm{D}$ & IIt & $\begin{array}{l}\text { Gerritsen } \\
\text { PLoSOne } \\
\quad(2017) \text { [57] } \\
\text { Patsios } \\
\quad \text { Respir Med } \\
\quad(2010) \text { [56] }\end{array}$ \\
\hline $\begin{array}{l}\text { Respiratory } \\
\text { symptoms }\end{array}$ & To diagnose pneumonia & $\begin{array}{l}\text { Thoracic CT scan without } \\
\text { contrast enhancement }\end{array}$ & $\mathrm{A}$ & IIu & $\begin{array}{l}\text { Gerritsen } \\
\quad \text { PLoSOne } \\
\quad(2017) \text { [57] }\end{array}$ \\
\hline $\begin{array}{l}\text { Persistent } \\
\text { fever for } \\
>96 \mathrm{~h} \\
\text { despite } \\
\text { broad } \\
\text { antibacterial } \\
\text { therapy }\end{array}$ & To diagnose pneumonia & $\begin{array}{l}\text { Thoracic CT scan without } \\
\text { contrast enhancement }\end{array}$ & $\mathrm{A}$ & IIu & $\begin{array}{l}\text { Gerritsen } \\
\quad \text { PLoSOne } \\
\text { (2017) [57] }\end{array}$ \\
\hline $\begin{array}{l}\text { Fever, } \\
\text { neutropeni- } \\
\text { a, and } \\
\text { pulmonary } \\
\text { infiltrates }\end{array}$ & $\begin{array}{l}\text { To identify causative } \\
\text { pathogens, for example } \\
\text { P. jirovecii, } \\
\text { Gram-negative bacteri- } \\
\text { a, pneumococci, } \\
\text { Nocardia } \text { spp., } \\
\text { M. tuberculosis, } \\
\text { Aspergillus spp., } \\
\text { Mucorales spp., } \\
\text { respiratory viruses, incl. } \\
\text { SARS-CoV-2 }\end{array}$ & $\begin{array}{l}\text { Bronchoscopy, bronchial } \\
\text { or bronchoalveolar } \\
\text { lavage (histology, } \\
\text { cytology, culture, } \\
\text { antigen testing, nucleic } \\
\text { acid testing) }\end{array}$ & A & III & $\begin{array}{l}\text { Marchesi AJH } \\
\text { (2019) [114] }\end{array}$ \\
\hline
\end{tabular}


levofloxacin [10]. Of note, levofloxacin is not approved for antibacterial prophylaxis in Germany. An increasingly critical view of fluoroquinolone prophylaxis is explained by the absence of a survival benefit of fluoroquinolone prophylaxis in randomized clinical trials as well as by toxicities associated with fluoroquinolone use $[58,59]$. Fluoroquinolone-resistant Enterobacteriaceae have been linked to community fluoroquinolone consumption. Prophylactic efficacy is reduced in neutropenic patients when the prevalence of fluoroquinolone resistance exceeds $20 \%$ in Gram-negative bacteria [60].

In summary, AGIHO recommends to critically weigh expected benefits of fluoroquinolone prophylaxis against the risks and consider local bacterial epidemiology and individual patient risk factors for fatal outcome of infections. AGIHO strongly recommends fluoroquinolone prophylaxis if the intention is to prevent bacterial infection. It cannot be expected to reduce risk of death with such prophylaxis [58].

Clostridioides difficile enteritis occurred in $3 \%$ vs. $8 \%$ after HDC/ASCT in a randomized comparison of fidaxomicin versus placebo [61]. Since the incidence of $C$. difficile-associated diarrhoea was low in both the placebo and in the fidaxomicin arm, AGIHO does not recommend prophylaxis of $C$. difficile enteritis after HDC/ASCT in the clinical routine.

\section{Antifungal prophylaxis}

Available data do not support the prophylactic use of antifungals to prevent invasive fungal disease (IFD). Those are rare events after HDC/ASCT and no reduction in mortality has been found in patients after HDC/ASCT [62, 63]. This is particularly true for mould-active antifungal agents. Yet, antifungal prophylaxis might be considered on a case-by-case basis if severe and long-lasting immunosuppression is expected.

The value of protective room ventilation such as highefficiency particulate air (HEPA) filtration, positive pressure-directed airflow or laminar airflow is not well established for HDC/ASCT patients. During the last two decades, the use of air-filtered rooms has decreased as the incidence of filamentous fungal infections is extremely low in patients undergoing HDC/ASCT [64]. In a prospective clinical trial with $400 \mathrm{HDC} / \mathrm{ASCT}$ patients from nine transplant centres, no significant impact of HEPA filtration on the incidence of pneumonia, including IFD, or mortality rate was observed [65]. Thus, there are no data to mandate air-filtered rooms and AGIHO supports a recommendation of air-filtered rooms with marginal strength.

Prophylaxis against Pneumocystis jirovecii pneumonia (PJP) is efficacious with trimethoprim/sulfamethoxazole (TMP/SMX). A meta-analysis calculated an RR of 0.15 (95\% CI 0.04-0.62) for an HIV-negative immunosuppressed individual to experience PJP when receiving prophylaxis with TMP/SMX, with a reduction of $P$. jirovecii-related mortality but no effect on all-cause mortality [66]. Reflecting mostly low quality of evidence due to bias and imprecision, AGIHO moderately supports a recommendation of TMP/ SMX to prevent PJP after HDC/ASCT. If the administration of TMP/SMX is not feasible, alternatives are atovaquone, or pentamidine administered by inhalation or intravenously. These alternatives have not been studied in the HDC/ASCT setting and recommendations are transferred from other populations. The duration of $P$. jirovecii-directed prophylaxis should last for at least 3 months, preferably until the CD4+ T cell count stably exceeds $200 / \mu 1$.

\section{Antiviral prophylaxis}

There are no large randomized controlled trials that evaluate antiviral drugs to prevent herpes simplex virus (HSV) and varicella zoster virus (VZV) disease after HDC/ASCT. Newer studies-including recently published placebocontrolled vaccination trials - showed that HSV infection, in particular, gingivostomatitis, and herpes zoster are still of concern in these patients [67-69]. Noteworthy, herpes zoster also frequently occurred beyond 6 months post-transplant, particularly in unvaccinated patients [69]. Antiviral drug use was reported in $\sim 90 \%$ in this trial, with a duration of $>6$ months in $\sim 40 \%$ [69]. Several studies, including placebo-controlled studies and meta-analyses (but not focused on ASCT patients) showed that acyclovir is useful to prevent and treat HSV and VZV diseases [70, 71]. Thus, we strongly recommend acyclovir prophylaxis for at least 6 months, in particular, if CD34selected grafts are used [34, 72]. Inactivated VZV vaccine is strongly recommended for all seropositive HDC/ASCT patients [69].

Cytomegalovirus (CMV) infection (reactivation) has been reported in some patients of mainly retrospective analyses focused to patients with fever after HDC/ASCT [73, 74]. However, CMV disease, i.e. organ involvement, is very rare in this setting [74]. In summary, CMV is no major concern in patients after HDC/ASCT. AGIHO supports a recommendation against the use of CMV prophylaxis.

Human herpes virus 6 (HHV-6) and Epstein-Barr virus (EBV) infections are infrequent after $\mathrm{HDC} / \mathrm{ASCT}$ and routine prophylaxis is not recommended [75, 76]. However, EBV reactivation has been reported at a high frequency in patients with multiple sclerosis undergoing ASCT [77]. Thus, nucleic acid-based screening for EBV viremia at follow-up presentations and preemptive treatment with rituximab in the case of EBV infection should be considered in these patients.

Reactivation of viral hepatitis in patients after HDC/ASCT with previous or ongoing chronic $\mathrm{HBV}$ infection i.e. HBsAg and/or anti-HBc positivity is associated with considerable morbidity and mortality. Reactivation has long been prevented using lamivudine. Lamivudine resistance can reach more than $70 \%$ in primary treatment of viral hepatitis B after 
long-time therapy [78]. Here, viral clearance and HBeAg status, amongst others, are important risk factors for the development of resistance. Today, tenofovir and entecavir are antiviral substances with resistance rates of $1-5 \%$. Their prophylactic administration is safe even in combination with most of the conditioning regimens $[79,80]$. AGIHO strongly recommends the use of either tenofovir or entecavir in patients with HBsAg- and/or anti-HBc positivity. Patients should regularly be monitored for reactivation despite antiviral prophylaxis by HBV DNA measurements. In addition to patients after HDC/ ASCT, patients under steroid medication and patients after the use of anti-CD20-antibodies, e.g. during maintenance therapy after HDC/ASCT, are at high risk for HBV reactivation [81].

Notably, the presence of anti-HBc IgM indicates acute infection and should trigger HBV DNA PCR. In acute HBV infection, clinical priority will frequently be to treat hepatitis before continuing antineoplastic treatment. For negative HBV DNA PCR, a combination of HBsAg negativity, anti-HBc positivity, anti-HBs negativity most frequently is a sign of resolved infection. As it can also mirror low-level chronic infection or resolving acute infection, AGIHO recommends repeating such test to rule out a false-positive result for antiHBc. Likewise, virustatic prophylaxis as outlined before and close monitoring of HBV DNA load is recommended if this specific constellation is repeatedly documented.

AGIHO as well as the German standing committee on vaccination recently published separate guidelines on antiinfective vaccination measures against vaccine-preventable diseases with an own section on the situation after HDC/ ASCT [82, 83].

Recommendations on antimicrobial prophylaxis are summarized in Table 4.

Table 4 Antiinfective prophylaxis in HDC/ASCT recipients

\begin{tabular}{|c|c|c|c|c|c|}
\hline Population & Intention & Intervention & SoR & QoE & References \\
\hline Any & To prevent infection & Any fluoroquinolone & A & I & Bucaneve NEJM (2005) [58] \\
\hline Any & To reduce mortality & Any fluoroquinolone & $\mathrm{C}$ & I & $\begin{array}{l}\text { Bucaneve NEJM (2005) [58] } \\
\text { Signorelli TID (2020) [10] }\end{array}$ \\
\hline Any & To prevent IFD & $\begin{array}{l}\text { Primary prophylaxis with mould active } \\
\text { antifungal }\end{array}$ & $\mathrm{D}$ & II & Van Burik CID (2004) [63] \\
\hline Any & $\begin{array}{l}\text { To prevent invasive } \\
\text { candidiasis }\end{array}$ & $\begin{array}{l}\text { Primary prophylaxis with fluconazole } \\
400 \mathrm{mg} / \mathrm{d}\end{array}$ & $\mathrm{D}$ & I & $\begin{array}{l}\text { Van Burik CID (2004) [63] } \\
\text { Rotstein CID (1999) [62] } \\
\text { Goodman NEJM (1992) } \\
\quad[115]\end{array}$ \\
\hline Patients with previous IFD & $\begin{array}{l}\text { To prevent recurrence of } \\
\text { IFD }\end{array}$ & $\begin{array}{l}\text { Secondary prophylaxis with the last } \\
\text { successfully used antifungal }\end{array}$ & A & IIt & $\begin{array}{l}\text { Cornely Mycoses (2019) } \\
\text { [116] } \\
\text { Sun BBMT (2015) [117] }\end{array}$ \\
\hline Any & $\begin{array}{l}\text { To prevent invasive } \\
\text { fungal infection }\end{array}$ & $\begin{array}{l}\text { Protective room ventilation e.g. HEPA } \\
\text { filtration }\end{array}$ & $\mathrm{C}$ & IIu & $\begin{array}{l}\text { Vokurka JCN (2013) [65] } \\
\text { Dadd J Ped Oncol Nurs } \\
\quad(2003)[118]\end{array}$ \\
\hline Any & To prevent PJP & Cotrimoxazole & B & IIr & Stern Cochrane (2014) [66] \\
\hline Any & $\begin{array}{l}\text { To prevent HSV } \\
\text { reactivation }\end{array}$ & Acyclovir/valacyclovir & A & IIt & $\begin{array}{l}\text { Kawamura IJH (2015) [70] } \\
\text { Glenny Cochrane Database } \\
\quad \text { (2009) [119] }\end{array}$ \\
\hline $\begin{array}{l}\text { CD34-selected or enriched } \\
\text { transplant }\end{array}$ & $\begin{array}{l}\text { To prevent HSV } \\
\text { reactivation }\end{array}$ & Acyclovir/valacyclovir & A & IIu & $\begin{array}{l}\text { Van Laar JAMA (2014) [34] } \\
\text { Lin Int J Hematol (2008) [72] }\end{array}$ \\
\hline Seropositive for VZV & $\begin{array}{l}\text { To prevent VZV } \\
\text { reactivation }\end{array}$ & Vaccination & A & I & $\begin{array}{l}\text { Winston Lancet (2018) [69] } \\
\text { Dagnew Lancet ID (2019) } \\
\quad[120]\end{array}$ \\
\hline Any & $\begin{array}{l}\text { To prevent VZV } \\
\text { reactivation }\end{array}$ & Acyclovir & A & IIu & $\begin{array}{l}\text { Winston Lancet (2018) [69] } \\
\text { Kawamura IJH (2015) [70] } \\
\text { Sahoo BBMT (2017) [121] } \\
\text { Seo Antivir Res (2017) [122] }\end{array}$ \\
\hline $\begin{array}{l}\text { CD34-selected or enriched } \\
\text { transplant }\end{array}$ & $\begin{array}{l}\text { To prevent } \mathrm{VZV} \\
\text { reactivation }\end{array}$ & Acyclovir & A & IIu & Crippa BBMT (2002) [123] \\
\hline Any & $\begin{array}{l}\text { To reduce CMV } \\
\text { infection/disease }\end{array}$ & $\begin{array}{l}\text { CMV prophylaxis (e.g. with foscarnet or } \\
\text { acyclovir) }\end{array}$ & $\mathrm{D}$ & IIu & Boeckh JID (1995) [124] \\
\hline $\begin{array}{l}\text { HBs antigen or anti-HBc anti- } \\
\text { body positive }\end{array}$ & $\begin{array}{l}\text { To prevent hepatitis } \mathrm{B} \\
\text { reactivation }\end{array}$ & Tenofovir or entecavir & A & IIt & $\begin{array}{l}\text { Huang JCO (2013) [125] } \\
\text { Lau Gastroenterol (2003) } \\
\quad[126]\end{array}$ \\
\hline
\end{tabular}




\section{Empiric antimicrobial therapy of fever of unknown origin}

Empiric treatment of FUO during neutropenia after HDC/ ASCT should follow recently published guidelines on the management of high-risk febrile neutropenia [18]. In summary, AGIHO strongly recommends to use single-agent broadspectrum Pseudomonas-active antibiotics such as piperacillin/ tazobactam, ceftazidime, cefepime, meropenem or imipenem/ cilastatin as first line antibiotic therapy $[18,84]$. As there is no systematic data on the empiric use of doripenem [85], ceftazidime-avibactam [86], ceftolozane-tazobactam [87] or cefozopran [88] in this setting, they are not discussed here. The upfront routine addition of tigecycline to first-line betalactam with anti-pseudomonal activity did not reduce the mortality rate and is therefore not recommended outside settings of high-level multidrug resistance [84]. Upfront addition of antibiotics with activity against Gram-positive bacteria such as glycopeptides (e.g. vancomycin, teicoplanin) [89], oxazolidinones (e.g. linezolid) or cyclic lipopeptides (e.g. daptomycin) has either shown no benefit or has not been studied properly, thus, we do not recommend their use. In patients with known colonization by VRE, addition of linezolid was not beneficial $[90,91]$. The administration of antimicrobial agents active against MRSA or ESBL-producing Gram-negative bacteria is recommended with marginal strength in case of colonization with these pathogens. The addition of an aminoglycoside in clinically stable patients in first-line therapy is not recommended [92-94]. However, in case of clinical instability, their addition is moderately recommended as might the addition of glycopeptides. Changing the first-line antibiotic regimen in a clinically stable patient who is still febrile after $>96 \mathrm{~h}$ is not generally recommended [18, 95, 96].

Empiric use of antifungals during first-line therapy in a clinically stable patient with FUO after HDC/ASCT is not recommended [97-99]. However, second-line addition of a mould-active antifungal is recommended with marginal strength for patients with persisting fever for at least $96 \mathrm{~h}$ receiving a broad-spectrum first-line antibacterial therapy who had not received prior antifungal prophylaxis and

Table 5 Empirical antimicrobial therapy in HDC/ASCT recipients

\begin{tabular}{|c|c|c|c|c|c|}
\hline Population & Intention & Intervention & SoR & QoE & References \\
\hline Patients at onset of fever & $\begin{array}{l}\text { To treat } \\
\text { presumed } \\
\text { underlying } \\
\text { infection }\end{array}$ & $\begin{array}{l}\text { Broad-spectrum antibiotics (piperacillin/tazobactam, } \\
\text { ceftazidime, cefepime, meropenem, imipenem/cilastatin) }\end{array}$ & A & I & $\begin{array}{c}\text { Bucaneve JCO } \\
(2014)[84] \\
\text { Reich BJH } \\
\text { (2005) [127] } \\
\text { Horita CMI } \\
\text { (2017) [128] } \\
\text { Harter BMT } \\
\quad(2006)[129]\end{array}$ \\
\hline $\begin{array}{l}\text { Patients at onset of fever, clinically } \\
\text { stable }\end{array}$ & $\begin{array}{l}\text { To treat } \\
\text { presumed } \\
\text { underlying } \\
\text { infection }\end{array}$ & Add aminoglycoside & $\mathrm{D}$ & I & $\begin{array}{l}\text { Del Favero CID } \\
\quad \text { (2001) [92] }\end{array}$ \\
\hline $\begin{array}{l}\text { Patients at fever onset, hospital } \\
\text { with high rates of multidrug } \\
\text { resistant bacteria }\end{array}$ & $\begin{array}{l}\text { To treat } \\
\text { presumed } \\
\text { underlying } \\
\text { infection }\end{array}$ & $\begin{array}{l}\text { Add antibiotics as appropriate (e.g. novel combinations of } \\
\text { cephalosporins and betalactamase inhibitors, siderophore } \\
\text { cephalosporins, tigecycline) }\end{array}$ & A & I & $\begin{array}{l}\text { Bucaneve JCO } \\
\text { (2014) [84] }\end{array}$ \\
\hline $\begin{array}{l}\text { Patients at fever onset or with } \\
\text { persisting fever }\end{array}$ & $\begin{array}{l}\text { To treat } \\
\text { presumed } \\
\text { underlying } \\
\text { infection }\end{array}$ & Add glycopeptide or oxazolidinone (e.g. linezolid) & $\mathrm{D}$ & I & $\begin{array}{l}\text { Cometta CID } \\
\quad(2003)[96] \\
\text { Lisboa IJID } \\
\quad(2015)[90]\end{array}$ \\
\hline $\begin{array}{l}\text { Patients with fever persisting } \\
>96 \text { h, clinically stable }\end{array}$ & $\begin{array}{l}\text { To treat } \\
\text { presumed } \\
\text { underlying } \\
\text { infection }\end{array}$ & Continue first line antibiotic treatment & A & I & $\begin{array}{l}\text { Bow CID } \\
\quad(2006)[130] \\
\text { Cometta CID } \\
\quad(2003)[96]\end{array}$ \\
\hline Patients with a first fever & $\begin{array}{l}\text { To treat } \\
\text { presumed } \\
\text { underlying } \\
\text { infection }\end{array}$ & Add antifungal & $\mathrm{D}$ & IIt & $\begin{array}{l}\text { Maschmeyer } \\
\text { EJCMID } \\
\text { (2013) [131] }\end{array}$ \\
\hline $\begin{array}{l}\text { Patients with fever persisting } \\
>96 \text { h, clinically stable }\end{array}$ & $\begin{array}{l}\text { To treat } \\
\text { presumed } \\
\text { underlying } \\
\text { infection }\end{array}$ & Add liposomal amphotericin B or caspofungin & $\mathrm{C}$ & IIt & $\begin{array}{c}\text { Walsh NEJM } \\
(2004)[132] \\
\text { Walsh NEJM } \\
1999[133]\end{array}$ \\
\hline
\end{tabular}


who are expected to experience neutropenia for more than 7 days [97-99]. This is not recommended if a mouldactive antifungal prophylaxis had been administered prior to signs of infection or fever. For second-line empiric antifungal therapy, caspofungin or liposomal amphotericin B are preferred, while conventional amphotericin B deoxycholate is not recommended due to an unfavourable toxicity profile.

Recommendations on empiric antimicrobial therapy are summarized in Table 5.

\section{Clinically documented infections}

Recommendations on management of pulmonary infiltrates [22], gastrointestinal and perineal infections [23], central nervous system infection [25], central venous catheter-related infection [24] and invasive fungal infections [21] can be found in the respective guidelines of the Infectious Diseases Working Party (AGIHO) of the German Society of Haematology and Medical Oncology (DGHO).

\section{Compliance with ethical standards}

Conflict of interest Maximilian Christopeit reports personal fees from Merck/MSD, GILEAD, Basilea, Pfizer, IQONE, Shionogi, non-financial support and other from Robert-Koch-Institut during the conduct of the study; others from Celgene, personal fees from JAZZ, Stemline, outside the submitted work.

Martin Schmidt-Hieber has received financial support for educational meetings at the Carl-Thiem-Klinikum, Cottbus/Germany from the following companies: Janssen-Cilag, Takeda, Novartis, Pfizer, Roche, Vifor and Celgene.

Rosanne Sprute declares that she has no conflict of interest.

Dieter Buchheidt reports personal fees from Gilead Sciences, Pfizer and Merck Sharp \& Dohme/Merck, outside the submitted work.

Marcus Hentrich declares that he has no conflict of interest.

Meinolf Karthaus reports personal fees from Riemser, Roche, Celgene and Servier, outside the submitted work.

Olaf Penack reports personal fees from Astellas, Merck/MSD, Shionogi, Pfizer, Omeros and grants from Incyte, outside the submitted work.

Markus Ruhnke declares that he has no conflict of interest.

Florian Weissinger reports personal fees from Roche, Novartis, Sanofi, Janssen and Pfizer, outside the submitted work.

Oliver A. Cornely is supported by the German Federal Ministry of Research and Education, is funded by the Deutsche Forschungsgemeinschaft (DFG, German Research Foundation) under Germany's Excellence Strategy_CECAD, EXC 2030-390661388 and has received research grants from Actelion, Amplyx, Astellas, Basilea, Cidara, Da Volterra, F2G, Gilead, Janssen Pharmaceuticals, Medicines Company, MedPace, Melinta Therapeutics, Merck/MSD, Pfizer and Scynexis; a consultant to Actelion, Allecra Therapeutics, AlJazeera Pharmaceuticals, Amplyx, Astellas, Basilea, Biosys UK Limited, Cidara, Da Volterra, Entasis, F2G, Gilead, Matinas, MedPace, Menarini Ricerche, Merck/MSD, Mylan Pharmaceuticals, Nabriva Therapeutics, Octapharma, Paratek Pharmaceuticals, Pfizer, PSI, Rempex, Roche Diagnostics Scynexis, Seres Therapeutics, Tetraphase and Vical; and received lecture honoraria from Astellas, Basilea, Gilead, Grupo Biotoscana, Merck/MSD and Pfizer.
Georg Maschmeyer reports personal fees from Gilead, Merck-Serono, Astra Zeneca and AMGEN and personal fees and non-financial support from Janssen Cilag, outside the submitted work.

Ethical approval This article does not contain any studies with human participants or animals performed by any of the authors.

Open Access This article is licensed under a Creative Commons Attribution 4.0 International License, which permits use, sharing, adaptation, distribution and reproduction in any medium or format, as long as you give appropriate credit to the original author(s) and the source, provide a link to the Creative Commons licence, and indicate if changes were made. The images or other third party material in this article are included in the article's Creative Commons licence, unless indicated otherwise in a credit line to the material. If material is not included in the article's Creative Commons licence and your intended use is not permitted by statutory regulation or exceeds the permitted use, you will need to obtain permission directly from the copyright holder. To view a copy of this licence, visit http://creativecommons.org/licenses/by/4.0/.

\section{References}

1. Attal M, Lauwers-Cances V, Hulin C, Leleu X, Caillot D, Escoffre M, Arnulf B, Macro M, Belhadj K, Garderet L, Roussel M, Payen C, Mathiot C, Fermand JP, Meuleman N, Rollet S, Maglio ME, Zeytoonjian AA, Weller EA, Munshi N, Anderson KC, Richardson PG, Facon T, Avet-Loiseau H, Harousseau JL, Moreau P, Study IFM (2017) Lenalidomide, bortezomib, and dexamethasone with transplantation for myeloma. N Engl J Med 376(14):1311-1320. https://doi.org/10.1056/NEJMoa1611750

2. Hermine O, Hoster E, Walewski J, Bosly A, Stilgenbauer S, Thieblemont C, Szymczyk M, Bouabdallah R, Kneba M, Hallek M, Salles G, Feugier P, Ribrag V, Birkmann J, Forstpointner R, Haioun C, Hanel M, Casasnovas RO, Finke J, Peter N, Bouabdallah K, Sebban C, Fischer T, Duhrsen U, Metzner B, Maschmeyer G, Kanz L, Schmidt C, Delarue R, Brousse N, Klapper W, Macintyre E, Delfau-Larue MH, Pott C, Hiddemann W, Unterhalt M, Dreyling M, European Mantle Cell Lymphoma N (2016) Addition of high-dose cytarabine to immunochemotherapy before autologous stem-cell transplantation in patients aged 65 years or younger with mantle cell lymphoma (MCL younger): a randomised, open-label, phase 3 trial of the European Mantle Cell Lymphoma Network. Lancet 388(10044):565-575. https://doi.org/10.1016/S0140-6736(16) 00739-X

3. Jurinovic V, Metzner B, Pfreundschuh M, Schmitz N, Wandt H, Keller U, Dreger P, Dreyling M, Hiddemann W, Unterhalt M, Hoster E, Weigert O (2018) Autologous stem cell transplantation for patients with early progression of follicular lymphoma: a follow-up study of 2 randomized trials from the German Low Grade Lymphoma Study Group. Biol Blood Marrow Transplant 24(6):1172-1179. https://doi.org/10.1016/j.bbmt.2018.03.022

4. Christopeit M, Labopin M, Gorin NC, Saraceni F, Passweg J, Forcade E, Maertens J, Van Lint MT, Bosi A, Niederwieser D, Ehninger G, Polge E, Mohty M, Nagler A (2018) Allogeneic stem cell transplantation following relapse post autologous stem cell transplantation in adult patients with acute myeloid leukemia: a retrospective analysis of 537 patients from the Acute Leukemia Working Party of the EBMT. Am J Hematol 93(12):1532-1542. https://doi.org/10.1002/ajh.25285

5. Pagliaro LC (2017) Role of high-dose chemotherapy with autologous stem-cell rescue in men with previously treated germ cell 
tumors. J Clin Oncol 35(10):1036-1040. https://doi.org/10.1200/ JCO.2016.70.6523

6. Muraro PA, Pasquini M, Atkins HL, Bowen JD, Farge D, Fassas A, Freedman MS, Georges GE, Gualandi F, Hamerschlak N, Havrdova E, Kimiskidis VK, Kozak T, Mancardi GL, Massacesi L, Moraes DA, Nash RA, Pavletic S, Ouyang J, Rovira M, Saiz A, Simoes B, Trneny M, Zhu L, Badoglio M, Zhong X, Sormani MP, Saccardi R, Multiple Sclerosis-Autologous Hematopoietic Stem Cell Transplantation Long-term Outcomes Study G (2017) Long-term outcomes after autologous hematopoietic stem cell transplantation for multiple sclerosis. JAMA Neurology 74(4): 459-469. https://doi.org/10.1001/jamaneurol.2016.5867

7. Sullivan KM, Goldmuntz EA, Keyes-Elstein L, McSweeney PA, Pinckney A, Welch B, Mayes MD, Nash RA, Crofford LJ, Eggleston B, Castina S, Griffith LM, Goldstein JS, Wallace D, Craciunescu O, Khanna D, Folz RJ, Goldin J, St Clair EW, Seibold JR, Phillips K, Mineishi S, Simms RW, Ballen K, Wener MH, Georges GE, Heimfeld S, Hosing C, Forman S, Kafaja S, Silver RM, Griffing L, Storek J, LeClercq S, Brasington R, Csuka ME, Bredeson C, Keever-Taylor C, Domsic RT, Kahaleh MB, Medsger T, Furst DE, Investigators SS (2018) Myeloablative autologous stem-cell transplantation for severe scleroderma. N Engl J Med 378(1):35-47. https://doi. org/10.1056/nejmoa1703327

8. Brierley CK, Castilla-Llorente C, Labopin M, Badoglio M, Rovira M, Ricart E, Dierickx D, Vermeire S, Hasselblatt P, Finke J, Onida F, Cassinotti A, Satsangi J, Kazmi M, Lopez-Sanroman A, Schmidt C, Farge D, Travis SPL, Hawkey CJ, Snowden JA, European Society for B, Marrow Transplantation Autoimmune Diseases Working P (2018) Autologous haematopoietic stem cell transplantation for Crohn's disease: a retrospective survey of longterm outcomes from the European Society for Blood and Marrow Transplantation. J Crohn's Colitis 12(9):1097-1103. https://doi. org/10.1093/ecco-jcc/jjy069

9. Passweg JR, Baldomero H, Chabannon C, Basak GW, Corbacioglu S, Duarte R, Dolstra H, Lankester AC, Mohty M, Montoto S, Peffault de Latour R, Snowden JA, Styczynski J, Yakoub-Agha I, Kroger N, European Society for B, Marrow T (2020) The EBMT activity survey on hematopoietic-cell transplantation and cellular therapy 2018: CAR-T's come into focus. Bone Marrow Transplant 55(8):1604-1613. https://doi.org/10. 1038/s41409-020-0826-4

10. Signorelli J, Zimmer A, Liewer S, Shostrom VK, Freifeld A (2020) Incidence of febrile neutropenia in autologous hematopoietic stem cell transplant (HSCT) recipients on levofloxacin prophylaxis. Transpl Infect Dis 22(2):e13225. https://doi.org/10. 1111/tid.13225

11. Girmenia C, Bertaina A, Piciocchi A, Perruccio K, Algarotti A, Busca A, Cattaneo C, Raiola AM, Guidi S, Iori AP, Candoni A, Irrera G, Milone G, Marcacci G, Scime R, Musso M, Cudillo L, Sica S, Castagna L, Corradini P, Marchesi F, Pastore D, Alessandrino EP, Annaloro C, Ciceri F, Santarone S, Nassi L, Farina C, Viscoli C, Rossolini GM, Bonifazi F, Rambaldi A, Gruppo Italiano Trapianto di Midollo O, Associazione Microbiologi Clinici I (2017) Incidence, risk factors and outcome of pre-engraftment Gram-negative bacteremia after allogeneic and autologous hematopoietic stem cell transplantation: an Italian prospective multicenter survey. Clin Infect Dis 65(11):1884-1896. https://doi.org/10.1093/cid/cix690

12. Averbuch D, Tridello G, Hoek J, Mikulska M, Akan H, Yanez San Segundo L, Pabst T, Ozcelik T, Klyasova G, Donnini I, Wu D, Gulbas Z, Zuckerman T, Botelho de Sousa A, Beguin Y, Xhaard A, Bachy E, Ljungman P, de la Camara R, Rascon J, Ruiz Camps I, Vitek A, Patriarca F, Cudillo L, Vrhovac R, Shaw PJ, Wolfs T, O'Brien T, Avni B, Silling G, Al Sabty F, Graphakos S, Sankelo M, Sengeloev H, Pillai S, Matthes S,
Melanthiou F, Iacobelli S, Styczynski J, Engelhard D, Cesaro S (2017) Antimicrobial resistance in Gram-negative rods causing bacteremia in hematopoietic stem cell transplant recipients: intercontinental prospective study of the Infectious Diseases Working Party of the European Bone Marrow Transplantation Group. Clin Infect Dis 65(11):1819-1828. https://doi.org/10.1093/cid/cix646

13. Marchesi F, Pimpinelli F, Di Domenico EG, Renzi D, Gallo MT, Regazzo G, Rizzo MG, Gumenyuk S, Toma L, Marino M, Cordone I, Cantonetti M, Liberati AM, Montanaro M, Ceribelli A, Prignano G, Palombi F, Romano A, Papa E, Pisani F, Spadea A, Arcese W, Ensoli F, Mengarelli A (2019) Association between CMV and invasive fungal infections after autologous stem cell transplant in lymphoproliferative malignancies: opportunistic partnership or cause-effect relationship? Int J Mol Sci 20(6). https://doi.org/10.3390/ijms20061373

14. Kontoyiannis DP, Marr KA, Park BJ, Alexander BD, Anaissie EJ, Walsh TJ, Ito J, Andes DR, Baddley JW, Brown JM, Brumble LM, Freifeld AG, Hadley S, Herwaldt LA, Kauffman CA, Knapp K, Lyon GM, Morrison VA, Papanicolaou G, Patterson TF, Perl TM, Schuster MG, Walker R, Wannemuehler KA, Wingard JR, Chiller TM, Pappas PG (2010) Prospective surveillance for invasive fungal infections in hematopoietic stem cell transplant recipients, 2001-2006: overview of the Transplant-Associated Infection Surveillance Network (TRANSNET) Database. Clin Infect Dis 50(8):1091-1100. https://doi.org/10.1086/651263

15. Maschmeyer G, Hertenstein B, Glass B, Schiel X (1999) Interventional antimicrobial therapy for febrile complications after high-dose chemotherapy and autologous stem cell transplantation. Standard recommendations of the Work Group of Infections in Hematology and Oncology of the German Association of Hematology and Oncology. Dtsch Med Wochenschr 124(Suppl 1):S9-S13

16. Bertz H, Auner HW, Weissinger F, Salwender HJ, Einsele H, Egerer G, Sandherr M, Schuttrumpf S, Sudhoff T, Maschmeyer G, Infectious Diseases Working Party of the German Society of H, Oncology (2003) Antimicrobial therapy of febrile complications after high-dose chemo-/radiotherapy and autologous hematopoietic stem cell transplantation-guidelines of the Infectious Diseases Working Party (AGIHO) of the German Society of Hematology and Oncology (DGHO). Ann Hematol 82 Suppl 2:S167-S174. doi:https://doi.org/10.1007/s00277-003-0771-5

17. Weissinger F, Auner HW, Bertz H, Buchheidt D, Cornely OA, Egerer G, Heinz W, Karthaus M, Kiehl M, Kruger W, Penack O, Reuter S, Ruhnke M, Sandherr M, Salwender HJ, Ullmann AJ, Waldschmidt DT, Wolf HH (2012) Antimicrobial therapy of febrile complications after high-dose chemotherapy and autologous hematopoietic stem cell transplantation-guidelines of the Infectious Diseases Working Party (AGIHO) of the German Society of Hematology and Oncology (DGHO). Ann Hematol 91(8):1161-1174. https://doi.org/10.1007/s00277-012-1456-8

18. Heinz WJ, Buchheidt D, Christopeit M, von Lilienfeld-Toal M, Cornely OA, Einsele H, Karthaus M, Link H, Mahlberg R, Neumann S, Ostermann H, Penack O, Ruhnke M, Sandherr M, Schiel X, Vehreschild JJ, Weissinger F, Maschmeyer G (2017) Diagnosis and empirical treatment of fever of unknown origin (FUO) in adult neutropenic patients: guidelines of the Infectious Diseases Working Party (AGIHO) of the German Society of Hematology and Medical Oncology (DGHO). Ann Hematol 96(11):1775-1792. https://doi.org/10.1007/s00277-017-3098-3

19. Penack O, Becker C, Buchheidt D, Christopeit M, Kiehl M, von Lilienfeld-Toal M, Hentrich M, Reinwald M, Salwender H, Schalk E, Schmidt-Hieber M, Weber T, Ostermann H (2014) Management of sepsis in neutropenic patients: 2014 updated guidelines from the Infectious Diseases Working Party of the German Society of Hematology and Medical Oncology 
(AGIHO). Ann Hematol 93(7):1083-1095. https://doi.org/10. 1007/s00277-014-2086-0

20. Ruhnke M, Behre G, Buchheidt D, Christopeit M, Hamprecht A, Heinz W, Heussel CP, Horger M, Kurzai O, Karthaus M, Loffler J, Maschmeyer G, Penack O, Rieger C, Rickerts V, Ritter J, Schmidt-Hieber M, Schuelper N, Schwartz S, Ullmann A, Vehreschild JJ, von Lilienfeld-Toal M, Weber T, Wolf HH (2018) Diagnosis of invasive fungal diseases in haematology and oncology: 2018 update of the recommendations of the infectious diseases Working Party of the German Society for Hematology and Medical Oncology (AGIHO). Mycoses 61(11): 796-813. https://doi.org/10.1111/myc. 12838

21. Ruhnke M, Cornely OA, Schmidt-Hieber M, Alakel N, Boell B, Buchheidt D, Christopeit M, Hasenkamp J, Heinz WJ, Hentrich M, Karthaus M, Koldehoff M, Maschmeyer G, Panse J, Penack O, Schleicher J, Teschner D, Ullmann AJ, Vehreschild M, von Lilienfeld-Toal M, Weissinger F, Schwartz S (2020) Treatment of invasive fungal diseases in cancer patients - Revised 2019 Recommendations of the Infectious Diseases Working Party (AGIHO) of the German Society of Hematology and Oncology (DGHO). Mycoses 63(7):653-682. https://doi.org/10.1111/myc. 13082

22. Maschmeyer G, Carratala J, Buchheidt D, Hamprecht A, Heussel CP, Kahl C, Lorenz J, Neumann S, Rieger C, Ruhnke M, Salwender H, Schmidt-Hieber M, Azoulay E (2015) Diagnosis and antimicrobial therapy of lung infiltrates in febrile neutropenic patients (allogeneic SCT excluded): updated guidelines of the Infectious Diseases Working Party (AGIHO) of the German Society of Hematology and Medical Oncology (DGHO). Ann Oncol 26(1):21-33. https://doi.org/10.1093/annonc/mdu192

23. Schmidt-Hieber M, Bierwirth J, Buchheidt D, Cornely OA, Hentrich M, Maschmeyer G, Schalk E, Vehreschild JJ, Vehreschild M, Group AW (2018) Diagnosis and management of gastrointestinal complications in adult cancer patients: 2017 updated evidence-based guidelines of the Infectious Diseases Working Party (AGIHO) of the German Society of Hematology and Medical Oncology (DGHO). Ann Hematol 97(1):31-49. https://doi.org/10.1007/s00277-017-3183-7

24. Hentrich M, Schalk E, Schmidt-Hieber M, Chaberny I, Mousset S, Buchheidt D, Ruhnke M, Penack O, Salwender H, Wolf HH, Christopeit M, Neumann S, Maschmeyer G, Karthaus M, Infectious Diseases Working Party of the German Society of H, Medical O (2014) Central venous catheter-related infections in hematology and oncology: 2012 updated guidelines on diagnosis, management and prevention by the Infectious Diseases Working Party of the German Society of Hematology and Medical Oncology. Ann Oncol 25(5):936-947. https://doi.org/10.1093/ annonc/mdt545

25. Schmidt-Hieber M, Silling G, Schalk E, Heinz W, Panse J, Penack O, Christopeit M, Buchheidt D, Meyding-Lamade U, Hahnel S, Wolf HH, Ruhnke M, Schwartz S, Maschmeyer G (2016) CNS infections in patients with hematological disorders (including allogeneic stem-cell transplantation) - Guidelines of the Infectious Diseases Working Party (AGIHO) of the German Society of Hematology and Medical Oncology (DGHO). Ann Oncol 27(7): 1207-1225. https://doi.org/10.1093/annonc/mdw155

26. Ullmann AJ, Akova M, Herbrecht R, Viscoli C, Arendrup MC, Arikan-Akdagli S, Bassetti M, Bille J, Calandra T, Castagnola E, Cornely OA, Donnelly JP, Garbino J, Groll AH, Hope WW, Jensen HE, Kullberg BJ, Lass-Florl C, Lortholary O, Meersseman W, Petrikkos G, Richardson MD, Roilides E, Verweij PE, Cuenca-Estrella M, Group EFIS (2012) ESCMID* guideline for the diagnosis and management of Candida diseases 2012: adults with haematological malignancies and after haematopoietic stem cell transplantation (HCT). Clin Microbiol
Infect 18(Supp1 7):53-67. https://doi.org/10.1111/1469-0691. 12041

27. Cornely OA, Alastruey-Izquierdo A, Arenz D, Chen SCA, Dannaoui E, Hochhegger B, Hoenigl M, Jensen HE, Lagrou K, Lewis RE, Mellinghoff SC, Mer M, Pana ZD, Seidel D, Sheppard DC, Wahba R, Akova M, Alanio A, Al-Hatmi AMS, ArikanAkdagli S, Badali H, Ben-Ami R, Bonifaz A, Bretagne S, Castagnola E, Chayakulkeeree M, Colombo AL, Corzo-Leon DE, Drgona L, Groll AH, Guinea J, Heussel CP, Ibrahim AS, Kanj SS, Klimko N, Lackner M, Lamoth F, Lanternier F, LassFloerl C, Lee DG, Lehrnbecher T, Lmimouni BE, Mares M, Maschmeyer G, Meis JF, Meletiadis J, Morrissey CO, Nucci M, Oladele R, Pagano L, Pasqualotto A, Patel A, Racil Z, Richardson M, Roilides E, Ruhnke M, Seyedmousavi S, Sidharthan N, Singh N, Sinko J, Skiada A, Slavin M, Soman R, Spellberg B, Steinbach W, Tan BH, Ullmann AJ, Vehreschild JJ, Vehreschild M, Walsh TJ, White PL, Wiederhold NP, Zaoutis T, Chakrabarti A, Mucormycosis EMSGGGWG (2019) Global guideline for the diagnosis and management of mucormycosis: an initiative of the European Confederation of Medical Mycology in cooperation with the Mycoses Study Group Education and Research Consortium. Lancet Infect Dis 19(12):e405-e421. https://doi. org/10.1016/S1473-3099(19)30312-3

28. Bodey GP (1966) Infectious complications of acute leukemia. Medical Times 94(9):1076-1085

29. Roussel M, Moreau P, Huynh A, Mary JY, Danho C, Caillot D, Hulin C, Fruchart C, Marit G, Pegourie B, Lenain P, Araujo C, Kolb B, Randriamalala E, Royer B, Stoppa AM, Dib M, Dorvaux V, Garderet L, Mathiot C, Avet-Loiseau H, Harousseau JL, Attal M, Intergroupe Francophone d M (2010) Bortezomib and highdose melphalan as conditioning regimen before autologous stem cell transplantation in patients with de novo multiple myeloma: a phase 2 study of the Intergroupe Francophone du Myelome (IFM). Blood 115(1):32-37. https://doi.org/10.1182/blood-2009-06229658

30. Atkins HL, Bowman M, Allan D, Anstee G, Arnold DL, Bar-Or A, Bence-Bruckler I, Birch P, Bredeson C, Chen J, Fergusson D, Halpenny M, Hamelin L, Huebsch L, Hutton B, Laneuville P, Lapierre Y, Lee H, Martin L, McDiarmid S, O'Connor P, Ramsay T, Sabloff M, Walker L, Freedman MS (2016) Immunoablation and autologous haemopoietic stem-cell transplantation for aggressive multiple sclerosis: a multicentre singlegroup phase 2 trial. Lancet 388(10044):576-585. https://doi.org/ 10.1016/S0140-6736(16)30169-6

31. Muraro PA, Robins H, Malhotra S, Howell M, Phippard D, Desmarais C, de Paula Alves Sousa A, Griffith LM, Lim N, Nash RA, Turka LA (2014) T cell repertoire following autologous stem cell transplantation for multiple sclerosis. J Clin Invest 124 (3):1168-1172. doi:https://doi.org/10.1172/JCI71691

32. Darlington PJ, Stopnicki B, Touil T, Doucet JS, Fawaz L, Roberts ME, Boivin MN, Arbour N, Freedman MS, Atkins HL, Bar-Or A (2018) Natural killer cells regulate Th17 cells after autologous hematopoietic stem cell transplantation for relapsing remitting multiple sclerosis. Front Immunol 9:834. https://doi.org/10.3389/ fimmu.2018.00834

33. Mancardi GL, Sormani MP, Gualandi F, Saiz A, Carreras E, Merelli E, Donelli A, Lugaresi A, Di Bartolomeo P, Rottoli MR, Rambaldi A, Amato MP, Massacesi L, Di Gioia M, Vuolo L, Curro D, Roccatagliata L, Filippi M, Aguglia U, Iacopino P, Farge D, Saccardi R, Astims Haemato-Neurological Collaborative Group ObotADWPotEGfB, Marrow T, Blood AH-NCGObotADWPAotEGf, Marrow Transplantation E (2015) Autologous hematopoietic stem cell transplantation in multiple sclerosis: a phase II trial. Neurology 84(10):981-988. https://doi.org/10.1212/WNL.0000000000001329 
34. van Laar JM, Farge D, Sont JK, Naraghi K, Marjanovic Z, Larghero J, Schuerwegh AJ, Marijt EW, Vonk MC, Schattenberg AV, Matucci-Cerinic M, Voskuyl AE, van de Loosdrecht AA, Daikeler T, Kotter I, Schmalzing M, Martin T, Lioure B, Weiner SM, Kreuter A, Deligny C, Durand JM, Emery P, Machold KP, Sarrot-Reynauld F, Warnatz K, Adoue DF, Constans J, Tony HP, Del Papa N, Fassas A, Himsel A, Launay D, Lo Monaco A, Philippe P, Quere I, Rich E, Westhovens R, Griffiths B, Saccardi R, van den Hoogen FH, Fibbe WE, Socie G, Gratwohl A, Tyndall A, Group EESS (2014) Autologous hematopoietic stem cell transplantation vs intravenous pulse cyclophosphamide in diffuse cutaneous systemic sclerosis: a randomized clinical trial. JAMA: J Am Med Assoc 311(24):2490-2498. https://doi.org/10.1001/jama.2014.6368

35. Veeraputhiran M, Jain T, Deol A, Ayash L, Kim S, Dyson G, Bhutani D, Lum LG, Ratanatharathorn V, Uberti JP, Abidi MH (2015) BEAM conditioning regimen has higher toxicity compared with high-dose melphalan for salvage autologous hematopoietic stem cell transplantation in multiple myeloma. Clin Lymphoma Myeloma Leuk 15(9):531-535. https://doi.org/10.1016/j.clml. 2015.05.008

36. Ghazal SS, Stevens MP, Bearman GM, Edmond MB (2014) Utility of surveillance blood cultures in patients undergoing hematopoietic stem cell transplantation. Antimicrob Resist Infect Control 3:20. https://doi.org/10.1186/2047-2994-3-20

37. Nesher L, Chemaly RF, Shah DP, Mulanovich VE, Hosing C, Rolston KV (2014) Utility of routine surveillance blood cultures in asymptomatic allogeneic hematopoietic stem cell transplant recipients with indwelling central venous catheters at a comprehensive cancer center. Am J Infect Control 42(10):1084-1088. https:// doi.org/10.1016/j.ajic.2014.07.004

38. Metan G, Koc AN, Kaynar LG, Atalay A, Ozturk A, Eser B, Cetin $M$ (2013) What is the role of the (1->3)-beta-D-glucan assay in the screening of patients undergoing autologous haematopoietic stemcell transplantation? Mycoses 56(1):34-38. https://doi.org/10. 1111/j.1439-0507.2012.02195.x

39. Pischke S, Hiller J, Lutgehetmann M, Polywka S, Rybczynski M, Ayuk F, Lohse AW (2016) Blood-borne hepatitis E virus transmission: a relevant risk for immunosuppressed patients. Clin Infect Dis 63(4):569-570. https://doi.org/10.1093/cid/ciw309

40. Richtlinie zur Herstellung und Anwendung von hämatopoetischen Stammzellzubereitungen - Erste Fortschreibung (2019). Dtsch Arztebl. https://doi.org/10.3238/arztebl.2019.rl_haematop_sz02

41. Chen CY, Huang SY, Cheng A, Chou WC, Yao M, Tang JL, Tsay W, Sheng WH, Tien HF (2015) High risk of hepatitis B reactivation among patients with acute myeloid leukemia. PLoS One 10(5):e0126037. https://doi.org/10.1371/journal.pone.0126037

42. Jun CH, Kim BS, Oak CY, Lee DH, Cho E, Cho SB, Choi SK, Park CH, Joo YE, Lee JJ, Kim HJ (2017) HBV reactivation risk factors in patients with chronic $\mathrm{HBV}$ infection with low replicative state and resolved HBV infection undergoing hematopoietic stem cell transplantation in Korea. Hepatol Int 11(1):87-95. https://doi. org/10.1007/s12072-016-9747-0

43. Kim HY, Yoo JJ, Oh S, Yu SJ, Kim YJ, Yoon JH, Kim W, Jung YJ, Kim BH, Kim CM, Park JW, Lee JH (2018) Scoring system for risk stratification of viral reactivation during prophylactic antiviral treatment in Korean patients with hepatitis B undergoing anticancer chemotherapy: a multicenter study. J Med Virol 90(10): 1593-1603. https://doi.org/10.1002/jmv.25241

44. Kusumoto S, Tanaka Y, Suzuki R, Watanabe T, Nakata M, Takasaki H, Fukushima N, Fukushima T, Moriuchi Y, Itoh K, Nosaka K, Choi I, Sawa M, Okamoto R, Tsujimura H, Uchida T, Suzuki S, Okamoto M, Takahashi T, Sugiura I, Onishi Y, Kohri M, Yoshida S, Sakai R, Kojima M, Takahashi H, Tomita A, Maruyama D, Atsuta Y, Tanaka E, Suzuki T, Kinoshita T, Ogura M, Mizokami M, Ueda R (2015) Monitoring of hepatitis
B virus (HBV) DNA and risk of HBV reactivation in B-cell lymphoma: a prospective observational study. Clin Infect Dis 61(5): 719-729. https://doi.org/10.1093/cid/civ344

45. Lv JW, Chen YP, Huang XD, Zhou GQ, Chen L, Li WF, Tang LL, Mao YP, Guo Y, Xu RH, Ma J, Sun Y (2017) Hepatitis B virus screening and reactivation and management of patients with nasopharyngeal carcinoma: a large-scale, big-data intelligence platform-based analysis from an endemic area. Cancer 123(18): 3540-3549. https://doi.org/10.1002/cncr.30775

46. von Lilienfeld-Toal M, Berger A, Christopeit M, Hentrich M, Heussel CP, Kalkreuth J, Klein M, Kochanek M, Penack O, Hauf E, Rieger C, Silling G, Vehreschild M, Weber T, Wolf HH, Lehners N, Schalk E, Mayer K (2016) Community acquired respiratory virus infections in cancer patients-guideline on diagnosis and management by the Infectious Diseases Working Party of the German Society for Haematology and Medical Oncology. Eur J Cancer 67:200-212. https://doi.org/10.1016/j.ejca.2016.08. 015

47. von Lilienfeld-Toal M, Vehreschild JJ, Cornely O, Pagano L, Compagno F, Group EHAIDSW, Hirsch HH (2020) Frequently asked questions regarding SARS-CoV-2 in cancer patientsrecommendations for clinicians caring for patients with malignant diseases. Leukemia 34 (6):1487-Group EHA1494. doi:https://doi. org/10.1038/s41375-020-0832-y

48. Lee A, Mirrett S, Reller LB, Weinstein MP (2007) Detection of bloodstream infections in adults: how many blood cultures are needed? J Clin Microbiol 45(11):3546-3548. https://doi.org/10. 1128/JCM.01555-07

49. Cockerill FR 3rd, Wilson JW, Vetter EA, Goodman KM, Torgerson CA, Harmsen WS, Schleck CD, Ilstrup DM, Washington JA 2nd, Wilson WR (2004) Optimal testing parameters for blood cultures. Clin Infect Dis 38(12):1724-1730. https://doi.org/10.1086/421087

50. Guembe M, Rodriguez-Creixems M, Sanchez-Carrillo C, PerezParra A, Martin-Rabadan P, Bouza E (2010) How many lumens should be cultured in the conservative diagnosis of catheter-related bloodstream infections? Clin Infect Dis 50(12):1575-1579. https://doi.org/10.1086/652766

51. Seifert H, Cornely O, Seggewiss K, Decker M, Stefanik D, Wisplinghoff H, Fatkenheuer G (2003) Bloodstream infection in neutropenic cancer patients related to short-term nontunnelled catheters determined by quantitative blood cultures, differential time to positivity, and molecular epidemiological typing with pulsed-field gel electrophoresis. J Clin Microbiol 41(1):118 123. https://doi.org/10.1128/jcm.41.1.118-123.2003

52. Blot F, Nitenberg G, Chachaty E, Raynard B, Germann N, Antoun S, Laplanche A, Brun-Buisson C, Tancrede C (1999) Diagnosis of catheter-related bacteraemia: a prospective comparison of the time to positivity of hub-blood versus peripheral-blood cultures. Lancet 354(9184):1071-1077. https://doi.org/10.1016/s0140-6736(98) 11134-0

53. Park KH, Lee MS, Lee SO, Choi SH, Sung H, Kim MN, Kim YS, Woo JH, Kim SH (2014) Diagnostic usefulness of differential time to positivity for catheter-related candidemia. J Clin Microbiol 52(7):2566-2572. https://doi.org/10.1128/JCM. 00605-14

54. Kaasch AJ, Rieg S, Hellmich M, Kern WV, Seifert H (2014) Differential time to positivity is not predictive for central linerelated Staphylococcus aureus bloodstream infection in routine clinical care. J Inf Secur 68(1):58-61. https://doi.org/10.1016/j. jinf.2013.08.006

55. Bouzidi H, Emirian A, Marty A, Chachaty E, Laplanche A, Gachot B, Blot F (2018) Differential time to positivity of central and peripheral blood cultures is inaccurate for the diagnosis of Staphylococcus aureus long-term catheter-related sepsis. J Hosp Infect 99(2):192-199. https://doi.org/10.1016/j.jhin.2018.01.010 
56. Patsios D, Maimon N, Chung T, Roberts H, Disperati P, Minden M, Paul N (2010) Chest low-dose computed tomography in neutropenic acute myeloid leukaemia patients. Respir Med 104(4): 600-605. https://doi.org/10.1016/j.rmed.2009.11.003

57. Gerritsen MG, Willemink MJ, Pompe E, van der Bruggen T, van Rhenen A, Lammers JW, Wessels F, Sprengers RW, de Jong PA, Minnema MC (2017) Improving early diagnosis of pulmonary infections in patients with febrile neutropenia using low-dose chest computed tomography. PLoS One 12(2):e0172256. https:// doi.org/10.1371/journal.pone.0172256

58. Bucaneve G, Micozzi A, Menichetti F, Martino P, Dionisi MS, Martinelli G, Allione B, D'Antonio D, Buelli M, Nosari AM, Cilloni D, Zuffa E, Cantaffa R, Specchia G, Amadori S, Fabbiano F, Deliliers GL, Lauria F, Foa R, Del Favero A, Gruppo Italiano Malattie Ematologiche dell'Adulto Infection $\mathrm{P}$ (2005) Levofloxacin to prevent bacterial infection in patients with cancer and neutropenia. N Engl J Med 353(10):977-987. https:// doi.org/10.1056/NEJMoa044097

59. Fluoroquinolone and quinolone antibiotics: PRAC recommends restrictions on use. (2018). European Medicines Agency EMA/ $668915 / 2018$

60. Bow EJ (2011) Fluoroquinolones, antimicrobial resistance and neutropenic cancer patients. Curr Opin Infect Dis 24(6):545553. https://doi.org/10.1097/QCO.0b013e32834cf054

61. Mullane KM, Winston DJ, Nooka A, Morris MI, Stiff P, Dugan MJ, Holland H, Gregg K, Adachi JA, Pergam SA, Alexander BD, Dubberke ER, Broyde N, Gorbach SL, Sears PS (2019) A randomized, placebo-controlled trial of fidaxomicin for prophylaxis of Clostridium difficile-associated diarrhea in adults undergoing hematopoietic stem cell transplantation. Clin Infect Dis 68(2): 196-203. https://doi.org/10.1093/cid/ciy484

62. Rotstein C, Bow EJ, Laverdiere M, Ioannou S, Carr D, Moghaddam N (1999) Randomized placebo-controlled trial of fluconazole prophylaxis for neutropenic cancer patients: benefit based on purpose and intensity of cytotoxic therapy. The Canadian Fluconazole Prophylaxis Study Group. Clin Infect Dis 28(2):331-340. https://doi.org/10.1086/515128

63. van Burik JA, Ratanatharathorn V, Stepan DE, Miller CB, Lipton JH, Vesole DH, Bunin N, Wall DA, Hiemenz JW, Satoi Y, Lee JM, Walsh TJ, National Institute of A, Infectious Diseases Mycoses Study G (2004) Micafungin versus fluconazole for prophylaxis against invasive fungal infections during neutropenia in patients undergoing hematopoietic stem cell transplantation. Clin Infect Dis 39(10):1407-1416. https://doi.org/10.1086/422312

64. Hicheri Y, Einsele H, Martino R, Cesaro S, Ljungman P, Cordonnier C (2013) Environmental prevention of infection in stem cell transplant recipients: a survey of the Infectious Diseases Working Party of the European Group for Blood and Marrow Transplantation. Transpl Infect Dis 15(3):251-258. https://doi.org/10.1111/tid.12064

65. Vokurka S, Bystricka E, Svoboda T, Skoda Gorican IK, Sever M, Mazur E, Kopinska A, Pavlicova V, Mocanu O, Tanase A, Ghelase R, Zitkova M, Labudikova M, Raida L, HrabankovaNavratilova D, Bockova J (2014) The availability of HEPAfiltered rooms and the incidence of pneumonia in patients after haematopoietic stem cell transplantation (HSCT): results from a prospective, multicentre, eastern European study. J Clin Nurs 23(11-12):1648-1652. https://doi.org/10.1111/jocn.12286

66. Stern A, Green H, Paul M, Vidal L, Leibovici L (2014) Prophylaxis for Pneumocystis pneumonia (PCP) in non-HIV immunocompromised patients. Cochrane Database Syst Rev 10: CD005590. https://doi.org/10.1002/14651858.CD005590.pub3

67. Bastidas A, de la Serna J, El Idrissi M, Oostvogels L, Quittet P, Lopez-Jimenez J, Vural F, Pohlreich D, Zuckerman T, Issa NC, Gaidano G, Lee JJ, Abhyankar S, Solano C, Perez de Oteyza J, Satlin MJ, Schwartz S, Campins M, Rocci A, Vallejo Llamas C,
Lee DG, Tan SM, Johnston AM, Grigg A, Boeckh MJ, Campora L, Lopez-Fauqued M, Heineman TC, Stadtmauer EA, Sullivan KM, Collaborators Z-HSG (2019) Effect of recombinant zoster vaccine on incidence of herpes zoster after autologous stem cell transplantation: a randomized clinical trial. JAMA: J Am Med Assoc 322(2):123-133. https://doi.org/10.1001/jama.2019.9053

68. Curran D, Matthews S, Rowley SD, Young JH, Bastidas A, Anagnostopoulos A, Barista I, Chandrasekar PH, Dickinson M, El Idrissi M, Heras I, Milliken ST, Monserrat Coll J, Navarro Matilla MB, Oostvogels L, Piatkowska-Jakubas B, Quiel D, Sabry W, Schwartz S, Selleslag DLD, Sullivan KM, Theunissen K, Yegin ZA, Yeh SP, Zaja F, Szer J, Z-HSg c (2019) Recombinant zoster vaccine significantly reduces the impact on quality of life caused by herpes zoster in adult autologous hematopoietic stem cell transplant recipients: a randomized placebocontrolled trial (ZOE-HSCT). Biol Blood Marrow Transplant 25(12):2474-2481. https://doi.org/10.1016/j.bbmt.2019.07.036

69. Winston DJ, Mullane KM, Cornely OA, Boeckh MJ, Brown JW, Pergam SA, Trociukas I, Zak P, Craig MD, Papanicolaou GA, Velez JD, Panse J, Hurtado K, Fernsler DA, Stek JE, Pang L, Su SC, Zhao Y, Chan ISF, Kaplan SS, Parrino J, Lee I, Popmihajlov Z, Annunziato PW, Arvin A, Team VPT (2018) Inactivated varicella zoster vaccine in autologous haemopoietic stem-cell transplant recipients: an international, multicentre, randomised, doubleblind, placebo-controlled trial. Lancet 391(10135):2116-2127. https://doi.org/10.1016/S0140-6736(18)30631-7

70. Kawamura K, Hayakawa J, Akahoshi Y, Harada N, Nakano H, Kameda K, Ugai T, Wada H, Yamasaki R, Ishihara Y, Sakamoto K, Ashizawa M, Sato M, Terasako-Saito K, Kimura S, Kikuchi M, Nakasone H, Yamazaki R, Kanda J, Kako S, Tanihara A, Nishida J, Kanda Y (2015) Low-dose acyclovir prophylaxis for the prevention of herpes simplex virus and varicella zoster virus diseases after autologous hematopoietic stem cell transplantation. Int J Hematol 102(2):230-237. https://doi.org/10.1007/s12185-015$1810-4$

71. McDonald EM, de Kock J, Ram FS (2012) Antivirals for management of herpes zoster including ophthalmicus: a systematic review of high-quality randomized controlled trials. Antivir Ther 17(2):255-264. https://doi.org/10.3851/IMP2011

72. Lin PC, Lee MY, Lin JT, Hsiao LT, Chen PM, Chiou TJ (2008) Virus reactivation in high-risk non-Hodgkin's lymphoma patients after autologous CD34+-selected peripheral blood progenitor cell transplantation. Int J Hematol 87(4):434-439. https://doi.org/10. 1007/s12185-008-0053-Z

73. Jain T, John J, Kotecha A, Deol A, Saliminia T, Revankar S, Chandrasekar P (2016) Cytomegalovirus infection in autologous stem cell transplant recipients in the era of rituximab. Ann Hematol 95(8):1323-1327. https://doi.org/10.1007/s00277-0162700-4

74. Mengarelli A, Annibali O, Pimpinelli F, Riva E, Gumenyuk S, Renzi D, Cerchiara E, Piccioni L, Palombi F, Pisani F, Romano A, Spadea A, Papa E, Cordone I, Canfora M, Arcese W, Ensoli F, Marchesi F (2016) Prospective surveillance vs clinically driven approach for CMV reactivation after autologous stem cell transplant. J Infect 72(2):265-268. https://doi.org/10.1016/j.jinf.2015. 11.005

75. Balsat M, Pillet S, Tavernier E, Cacheux V, Escuret V, MoluconChabrot C, Augeul-Meunier K, Mirand A, Regagnon C, Tinquaut F, Bousser V, Oriol M, Guyotat D, Salles G, Bay JO, Pozzetto B, Cornillon J (2019) Human herpesvirus 6 infection after autologous stem cell transplantation: a multicenter prospective study in adult patients. J Infect 79(1):36-42. https://doi.org/10.1016/j.jinf.2019. 05.001

76. Inazawa $\mathrm{N}$, Hori $\mathrm{T}$, Nojima M, Saito M, Igarashi K, Yamamoto M, Shimizu N, Yoto Y, Tsutsumi H (2017) Virus reactivations after autologous hematopoietic stem cell transplantation detected 
by multiplex PCR assay. J Med Virol 89(2):358-362. https://doi. org/10.1002/jmv.24621

77. Mehra V, Rhone E, Widya S, Zuckerman M, Potter V, Raj K, Kulasekararaj A, McLornan D, de Lavallade H, Benson-Quarm N, Lim C, Ware S, Sudhanva M, Malik O, Nicholas R, Muraro PA, Marsh J, Mufti GJ, Silber E, Pagliuca A, Kazmi MA (2019) Epstein-Barr virus and monoclonal gammopathy of clinical significance in autologous stem cell transplantation for multiple sclerosis. Clin Infect Dis 69 (10):1757-1763. doi:https://doi.org/10. 1093/cid/ciz047

78. EASL 2017 Clinical practice guidelines on the management of hepatitis B virus infection (2017) J Hepatol 67(2):370-398. https://doi.org/10.1016/j.jhep.2017.03.021

79. Tenney DJ, Rose RE, Baldick CJ, Pokornowski KA, Eggers BJ, Fang J, Wichroski MJ, Xu D, Yang J, Wilber RB, Colonno RJ (2009) Long-term monitoring shows hepatitis B virus resistance to entecavir in nucleoside-naive patients is rare through 5 years of therapy. Hepatology 49(5):1503-1514. https://doi.org/10.1002/ hep. 22841

80. Jenh AM, Thio CL, Pham PA (2009) Tenofovir for the treatment of hepatitis B virus. Pharmacotherapy 29(10):1212-1227. https:// doi.org/10.1592/phco.29.10.1212

81. Choi J, Lim YS (2017) Characteristics, prevention, and management of hepatitis B virus (HBV) reactivation in HBV-infected patients who require immunosuppressive therapy. J Infect Dis 216(suppl 8):S778-S784. https://doi.org/10.1093/infdis/jix178

82. Rieger CT, Liss B, Mellinghoff S, Buchheidt D, Cornely OA, Egerer G, Heinz WJ, Hentrich M, Maschmeyer G, Mayer K, Sandherr M, Silling G, Ullmann A, Vehreschild M, von Lilienfeld-Toal M, Wolf HH, Lehners N, German Society of H, Medical Oncology Infectious Diseases Working G (2018) Antiinfective vaccination strategies in patients with hematologic malignancies or solid tumors-Guideline of the Infectious Diseases Working Party (AGIHO) of the German Society for Hematology and Medical Oncology (DGHO). Ann Oncol 29(6):1354-1365. https://doi.org/10.1093/annonc/mdy117

83. Laws HJ, Baumann U, Bogdan C, Burchard G, Christopeit M, Hecht J, Heininger U, Hilgendorf I, Kern W, Kling K, Kobbe G, Kulper W, Lehrnbecher T, Meisel R, Simon A, Ullmann A, de Wit M, Zepp F (2020). Bundesgesundheitsblatt Gesundheitsforschung Gesundheitsschutz 63 (5):588-644. doi:https://doi.org/10.1007/ s00103-020-03123-w

84. Bucaneve G, Micozzi A, Picardi M, Ballanti S, Cascavilla N, Salutari P, Specchia G, Fanci R, Luppi M, Cudillo L, Cantaffa R, Milone G, Bocchia M, Martinelli G, Offidani M, Chierichini A, Fabbiano F, Quarta G, Primon V, Martino B, Manna A, Zuffa E, Ferrari A, Gentile G, Foa R, Del Favero A (2014) Results of a multicenter, controlled, randomized clinical trial evaluating the combination of piperacillin/tazobactam and tigecycline in highrisk hematologic patients with cancer with febrile neutropenia. $\mathrm{J}$ Clin Oncol 32(14):1463-1471. https://doi.org/10.1200/JCO. 2013.51.6963

85. Toya T, Nannya Y, Narukawa K, Ichikawa M, Kurokawa M (2012) A comparative analysis of meropenem and doripenem in febrile patients with hematologic malignancies: a single-center retrospective study. Jpn J Infect Dis 65(3):228-232. https://doi. org/10.7883/yoken.65.228

86. Hachem R, Reitzel R, Rolston K, Chaftari AM, Raad I (2017) Antimicrobial activities of ceftazidime-avibactam and comparator agents against clinical bacteria isolated from patients with cancer. Antimicrob Agents Chemother 61(4):e02106-e2116. https://doi. org/10.1128/AAC.02106-16

87. Aitken SL, Kontoyiannis DP, DePombo AM, Bhatti MM, Tverdek FP, Gettys SC, Nicolau DP, Nunez CA (2016) Use of ceftolozane/tazobactam in the treatment of multidrug-resistant Pseudomonas aeruginosa bloodstream infection in a pediatric leukemia patient. Pediatr Infect Dis J 35(9):1040-1042. https:// doi.org/10.1097/INF.0000000000001228

88. Nakane T, Tamura K, Hino M, Tamaki T, Yoshida I, Fukushima T, Tatsumi Y, Nakagawa Y, Hatanaka K, Takahashi T, Akiyama N, Tanimoto M, Ohyashiki K, Urabe A, Masaoka T, Kanamaru A, Japan Febrile Neutropenia Study G (2015) Cefozopran, meropenem, or imipenem-cilastatin compared with cefepime as empirical therapy in febrile neutropenic adult patients: a multicenter prospective randomized trial. J Infect Chemother 21(1):16-22. https://doi.org/10.1016/j.jiac.2014.08.026

89. Vardakas KZ, Samonis G, Chrysanthopoulou SA, Bliziotis IA, Falagas ME (2005) Role of glycopeptides as part of initial empirical treatment of febrile neutropenic patients: a meta-analysis of randomised controlled trials. Lancet Infect Dis 5(7):431-439. https://doi.org/10.1016/S1473-3099(05)70164-X

90. Lisboa LF, Miranda BG, Vieira MB, Dulley FL, Fonseca GG, Guimaraes T, Levin AS, Shikanai-Yasuda MA, Costa SF (2015) Empiric use of linezolid in febrile hematology and hematopoietic stem cell transplantation patients colonized with vancomycinresistant Enterococcus spp. Int J Infect Dis 33:171-176. https:// doi.org/10.1016/j.ijid.2015.02.001

91. Kamboj M, Cohen N, Huang YT, Kerpelev M, Jakubowski A, Sepkowitz KA, Papanicolaou GA, Seo SK (2019) Impact of empiric treatment for vancomycin-resistant Enterococcus in colonized patients early after allogeneic hematopoietic stem cell transplantation. Biol Blood Marrow Transplant 25(3):594-598. https:// doi.org/10.1016/j.bbmt.2018.11.008

92. Del Favero A, Menichetti F, Martino P, Bucaneve G, Micozzi A, Gentile G, Furno P, Russo D, D'Antonio D, Ricci P, Martino B, Mandelli F, Gruppo Italiano Malattie Ematologiche dell'Adulto Infection P (2001) A multicenter, double-blind, placebocontrolled trial comparing piperacillin-tazobactam with and without amikacin as empiric therapy for febrile neutropenia. Clin Infect Dis 33 (8):1295-1301. doi:https://doi.org/10.1086/322646

93. Furno P, Bucaneve G, Del Favero A (2002) Monotherapy or aminoglycoside-containing combinations for empirical antibiotic treatment of febrile neutropenic patients: a meta-analysis. Lancet Infect Dis 2(4):231-242. https://doi.org/10.1016/s1473-3099(02) 00241-4

94. Paul M, Dickstein Y, Schlesinger A, Grozinsky-Glasberg S, Soares-Weiser K, Leibovici L (2013) Beta-lactam versus betalactam-aminoglycoside combination therapy in cancer patients with neutropenia. Cochrane Database Syst Rev 2013(6): CD003038. https://doi.org/10.1002/14651858.CD003038.pub2

95. Freifeld AG, Bow EJ, Sepkowitz KA, Boeckh MJ, Ito JI, Mullen CA, Raad RKV II, Young JA, Wingard JR, Infectious Diseases Society of A (2011) Clinical practice guideline for the use of antimicrobial agents in neutropenic patients with cancer: 2010 update by the infectious diseases society of america. Clin Infect Dis 52(4):e56-e93. https://doi.org/10.1093/cid/cir073

96. Cometta A, Kern WV, De Bock R, Paesmans M, Vandenbergh M, Crokaert F, Engelhard D, Marchetti O, Akan H, Skoutelis A, Korten V, Vandercam M, Gaya H, Padmos A, Klastersky J, Zinner S, Glauser MP, Calandra T, Viscoli C, International Antimicrobial Therapy Group of the European Organization for Research Treatment of C (2003) Vancomycin versus placebo for treating persistent fever in patients with neutropenic cancer receiving piperacillin-tazobactam monotherapy. Clin Infect Dis 37(3): 382-389. https://doi.org/10.1086/376637

97. Cordonnier C, Pautas C, Maury S, Vekhoff A, Farhat H, Suarez F, Dhedin N, Isnard F, Ades L, Kuhnowski F, Foulet F, Kuentz M, Maison P, Bretagne S, Schwarzinger M (2009) Empirical versus preemptive antifungal therapy for high-risk, febrile, neutropenic patients: a randomized, controlled trial. Clin Infect Dis 48(8): 1042-1051. https://doi.org/10.1086/597395 
98. Fung M, Kim J, Marty FM, Schwarzinger M, Koo S (2015) Metaanalysis and cost comparison of empirical versus pre-emptive antifungal strategies in hematologic malignancy patients with highrisk febrile neutropenia. PLoS One 10(11):e0140930. https://doi. org/10.1371/journal.pone.0140930

99. Maertens J, Theunissen K, Verhoef G, Verschakelen J, Lagrou K, Verbeken E, Wilmer A, Verhaegen J, Boogaerts M, Van Eldere J (2005) Galactomannan and computed tomography-based preemptive antifungal therapy in neutropenic patients at high risk for invasive fungal infection: a prospective feasibility study. Clin Infect Dis 41 (9):1242-1250. doi:https://doi.org/10.1086/496927

100. von Felden J, Alric L, Pischke S, Aitken C, Schlabe S, Spengler U, Giordani MT, Schnitzler P, Bettinger D, Thimme R, Xhaard A, Binder M, Ayuk F, Lohse AW, Cornelissen JJ, de Man RA, Mallet V (2019) The burden of hepatitis E among patients with haematological malignancies: a retrospective European cohort study. J Hepatol 71(3):465-472. https://doi.org/10.1016/j.jhep.2019.04. 022

101. Furfaro E, Nicolini L, Della Vecchia A, Di Grazia C, Raiola AM, Varaldo R, Ferrando F, Barisione G, Bruzzone B, Angelucci E, Viscoli C, Mikulska M (2020) Hepatitis E virus infection in an Italian cohort of hematopoietic stem cell transplantation recipients: seroprevalence and infection. Biol Blood Marrow Transplant 26 (7):1355-1362. doi:https://doi.org/10.1016/j.bbmt.2020.03.012

102. Marchesi F, Pimpinelli F, Ensoli F, Mengarelli A (2018) Cytomegalovirus infection in hematologic malignancy settings other than the allogeneic transplant. Hematol Oncol 36(2):381391. https://doi.org/10.1002/hon.2453

103. Kaya AH, Tekgunduz E, Akpinar S, Batgi H, Bekdemir F, Kayikci O, Namdaroglu S, Ulu BU, Dal MS, Cakar MK, Korkmaz S, Altuntas F (2017) Is cytomegalovirus surveillance necessary for patients with low reactivation risk in an autologous hematopoietic cell transplantation setting? Transplant Proc 49(8): 1911-1915. https://doi.org/10.1016/j.transproceed.2017.05.007

104. Massoud R, Assi R, Fares E, Haffar B, Charafeddine M, Kreidieh N, Mahfouz R, Kanj SS, El Zakhem A, Kharfan-Dabaja M, Bazarbachi A, El Cheikh J (2017) Cytomegalovirus reactivation in lymphoma and myeloma patients undergoing autologous peripheral blood stem cell transplantation. J Clin Virol 95:36-41. https://doi.org/10.1016/j.jcv.2017.08.006

105. Piukovics K, Terhes G, Gurbity-Palfi T, Bereczki A, Rarosi F, Deak J, Borbenyi Z, Urban E (2017) Cytomegalovirus infection in patients with haematological diseases and after autologous stem cell transplantation as consolidation: a single-centre study. Ann Hematol 96(1):125-131. https://doi.org/10.1007/s00277-0162831-7

106. Chiusolo P, Metafuni E, Cattani P, Piccirillo N, Santangelo R, Manzara S, Bellesi S, De Michele T, Leone G, Sica S (2010) Prospective evaluation of epstein-barr virus reactivation after stem cell transplantation: association with monoclonal gammopathy. J Clin Immunol 30(6):894-902. https://doi.org/10.1007/s10875010-9454-x

107. Piukovics K, Borbenyi Z, Rajda C, Csomor A, Deak J, Terhes G (2014) Monitoring human herpesvirus-6 in patients with autologous stem cell transplantation. Vivo 28(6):1113-1117

108. Duarte RF, Sanchez-Ortega I, Cuesta I, Arnan M, Patino B, Fernandez de Sevilla A, Gudiol C, Ayats J, Cuenca-Estrella M (2014) Serum galactomannan-based early detection of invasive aspergillosis in hematology patients receiving effective antimold prophylaxis. Clin Infect Dis 59(12):1696-1702. https://doi.org/ 10.1093/cid/ciu673

109. Hammarstrom H, Kondori N, Friman V, Wenneras C (2015) How to interpret serum levels of beta-glucan for the diagnosis of invasive fungal infections in adult high-risk hematology patients: optimal cut-off levels and confounding factors. Eur J Clin Microbiol
Infect Dis 34(5):917-925. https://doi.org/10.1007/s10096-0142302-9

110. Cornely OA, Leguay T, Maertens J, Vehreschild M, Anagnostopoulos A, Castagnola C, Verga L, Rieger C, Kondakci M, Harter G, Duarte RF, Allione B, Cordonnier C, Heussel CP, Morrissey CO, Agrawal SG, Donnelly JP, Bresnik M, Hawkins MJ, Garner W, Gokbuget N, AmBiGuard Study G (2017) Randomized comparison of liposomal amphotericin B versus placebo to prevent invasive mycoses in acute lymphoblastic leukaemia. J Antimicrob Chemother 72(8):2359-2367. https:// doi.org/10.1093/jac/dkx133

111. Bouza E, Alvarado N, Alcala L, Perez MJ, Rincon C, Munoz P (2007) A randomized and prospective study of 3 procedures for the diagnosis of catheter-related bloodstream infection without catheter withdrawal. Clin Infect Dis 44(6):820-826. https://doi. org/10.1086/511865

112. Planes AM, Calleja R, Bernet A, Campins-Marti M, Almirante B, Pumarola T, Fernandez-Hidalgo N (2016) Evaluation of the usefulness of a quantitative blood culture in the diagnosis of catheterrelated bloodstream infection: comparative analysis of two periods (2002 and 2012). Enferm Infecc Microbiol Clin 34(8):484-489. https://doi.org/10.1016/j.eimc.2015.11.007

113. Herrera-Guerra AS, Garza-Gonzalez E, Martinez-Resendez MF, Llaca-Diaz JM, Camacho-Ortiz A (2015) Individual versus pooled multiple-lumen blood cultures for the diagnosis of intravascular catheter-related infections. Am J Infect Control 43(7):715-718. https://doi.org/10.1016/j.ajic.2015.02.028

114. Marchesi F, Cattaneo C, Criscuolo M, Delia M, Dargenio M, Del Principe MI, Spadea A, Fracchiolla NS, Melillo L, Perruccio K, Alati C, Russo D, Garzia M, Brociner M, Cefalo M, Armiento D, Cesaro S, Decembrino N, Mengarelli A, Tumbarello M, Busca A, Pagano L, Sorveglianza Epidemiologica Infezioni nelle Emopatie G (2019) A bronchoalveolar lavage-driven antimicrobial treatment improves survival in hematologic malignancy patients with detected lung infiltrates: a prospective multicenter study of the SEIFEM group American Journal of Hematology 94 (10):1104 1112. doi:https://doi.org/10.1002/ajh.25585

115. Goodman JL, Winston DJ, Greenfield RA, Chandrasekar PH, Fox B, Kaizer H, Shadduck RK, Shea TC, Stiff P, Friedman DJ et al (1992) A controlled trial of fluconazole to prevent fungal infections in patients undergoing bone marrow transplantation. $\mathrm{N}$ Engl J Med 326(13):845-851. https://doi.org/10.1056/ NEJM199203263261301

116. Cornely OA, Hoenigl M, Lass-Florl C, Chen SC, Kontoyiannis DP, Morrissey CO, Thompson GR 3rd, Mycoses Study Group E, Research C, the European Confederation of Medical M (2019) Defining breakthrough invasive fungal infection-position paper of the mycoses study group education and research consortium and the European Confederation of Medical Mycology. Mycoses 62(9):716-729. https://doi.org/10.1111/myc.12960

117. Sun Y, Meng F, Han M, Zhang X, Yu L, Huang H, Wu D, Ren H, Wang C, Shen Z, Ji Y, Huang X (2015) Epidemiology, management, and outcome of invasive fungal disease in patients undergoing hematopoietic stem cell transplantation in China: a multicenter prospective observational study. Biol Blood Marrow Transplant 21(6):1117-1126. https://doi.org/10.1016/j.bbmt.2015.03.018

118. Dadd G, McMinn P, Monterosso L (2003) Protective isolation in hemopoietic stem cell transplants: a review of the literature and single institution experience. J Pediatr Oncol Nurs 20(6):293-300. https://doi.org/10.1177/1043454203254985

119. Glenny AM, Fernandez Mauleffinch LM, Pavitt S, Walsh T (2009) Interventions for the prevention and treatment of herpes simplex virus in patients being treated for cancer. Cochrane Database Syst Rev 1:CD006706. https://doi.org/10.1002/ 14651858.CD006706.pub2 
120. Dagnew AF, Ilhan O, Lee WS, Woszczyk D, Kwak JY, Bowcock S, Sohn SK, Rodriguez Macias G, Chiou TJ, Quiel D, Aoun M, Navarro Matilla MB, de la Serna J, Milliken S, Murphy J, McNeil SA, Salaun B, Di Paolo E, Campora L, Lopez-Fauqued M, El Idrissi M, Schuind A, Heineman TC, Van den Steen P, Oostvogels L, Zoster-039 s g (2019) Immunogenicity and safety of the adjuvanted recombinant zoster vaccine in adults with haematological malignancies: a phase 3, randomised, clinical trial and post-hoc efficacy analysis. Lancet Infect Dis 19(9):988-1000. https://doi.org/10.1016/S1473-3099(19)30163-X

121. Sahoo F, Hill JA, Xie H, Leisenring W, Yi J, Goyal S, Kimball LE, Lee I, Seo S, Davis C, Pergam SA, Flowers ME, Liaw KL, Holmberg L, Boeckh M (2017) Herpes zoster in autologous hematopoietic cell transplant recipients in the era of acyclovir or valacyclovir prophylaxis and novel treatment and maintenance therapies. Biol Blood Marrow Transplant 23(3):505-511. https:// doi.org/10.1016/j.bbmt.2016.12.620

122. Seo HM, Kim YS, Bang CH, Lee JH, Lee JY, Lee DG, Park YM (2017) Antiviral prophylaxis for preventing herpes zoster in hematopoietic stem cell transplant recipients: a systematic review and meta-analysis. Antivir Res 140:106-115. https://doi.org/10. 1016/j.antiviral.2017.01.011

123. Crippa F, Holmberg L, Carter RA, Hooper H, Marr KA, Bensinger W, Chauncey T, Corey L, Boeckh M (2002) Infectious complications after autologous CD34-selected peripheral blood stem cell transplantation. Biol Blood Marrow Transplant 8(5):281-289. https://doi.org/10.1053/bbmt.2002.v8. pm12064366

124. Boeckh M, Gooley TA, Reusser P, Buckner CD, Bowden RA (1995) Failure of high-dose acyclovir to prevent cytomegalovirus disease after autologous marrow transplantation. J Infect Dis 172(4):939-943. https://doi.org/10.1093/infdis/172.4.939

125. Huang YH, Hsiao LT, Hong YC, Chiou TJ, Yu YB, Gau JP, Liu CY, Yang MH, Tzeng CH, Lee PC, Lin HC, Lee SD (2013) Randomized controlled trial of entecavir prophylaxis for rituximab-associated hepatitis $\mathrm{B}$ virus reactivation in patients with lymphoma and resolved hepatitis B. J Clin Oncol 31(22):27652772. https://doi.org/10.1200/JCO.2012.48.5938

126. Lau GK, Yiu HH, Fong DY, Cheng HC, Au WY, Lai LS, Cheung M, Zhang HY, Lie A, Ngan R, Liang R (2003) Early is superior to deferred preemptive lamivudine therapy for hepatitis B patients undergoing chemotherapy. Gastroenterology 125(6):1742-1749. https://doi.org/10.1053/j.gastro.2003.09.026

127. Reich G, Cornely OA, Sandherr M, Kubin T, Krause S, Einsele H, Thiel E, Bellaire T, Dorken B, Maschmeyer G (2005) Empirical antimicrobial monotherapy in patients after high-dose chemotherapy and autologous stem cell transplantation: a randomised, multicentre trial. Br J Haematol 130(2):265-270. https://doi.org/10.1111/j.1365-2141.2005.05608.x

128. Horita N, Shibata Y, Watanabe H, Namkoong H, Kaneko T (2017) Comparison of antipseudomonal beta-lactams for febrile neutropenia empiric therapy: systematic review and network meta-analysis. Clin Microbiol Infect 23(10):723-729. https://doi.org/ 10.1016/j.cmi.2017.03.024

129. Harter C, Schulze B, Goldschmidt H, Benner A, Geiss HK, Hoppe-Tichy T, Ho AD, Egerer G (2006) Piperacillin/ tazobactam vs ceftazidime in the treatment of neutropenic fever in patients with acute leukemia or following autologous peripheral blood stem cell transplantation: a prospective randomized trial. Bone Marrow Transplant 37(4):373-379. https://doi.org/10. 1038/sj.bmt.1705256

130. Bow EJ, Rotstein C, Noskin GA, Laverdiere M, Schwarer AP, Segal BH, Seymour JF, Szer J, Sanche S (2006) A randomized, open-label, multicenter comparative study of the efficacy and safety of piperacillin-tazobactam and cefepime for the empirical treatment of febrile neutropenic episodes in patients with hematologic malignancies. Clin Infect Dis 43(4):447-459. https://doi.org/10. $1086 / 505393$

131. Maschmeyer G, Heinz WJ, Hertenstein B, Horst HA, Requadt C, Wagner T, Cornely OA, Loffler J, Ruhnke M, Is i (2013) Immediate versus deferred empirical antifungal (IDEA) therapy in high-risk patients with febrile neutropenia: a randomized, double-blind, placebo-controlled, multicenter study. Eur J Clin Microbiol Infect Dis 32(5):679-689. https://doi.org/10.1007/ s10096-012-1794-4

132. Walsh TJ, Teppler H, Donowitz GR, Maertens JA, Baden LR, Dmoszynska A, Cornely OA, Bourque MR, Lupinacci RJ, Sable CA, dePauw BE (2004) Caspofungin versus liposomal amphotericin B for empirical antifungal therapy in patients with persistent fever and neutropenia. N Engl J Med 351(14):13911402. https://doi.org/10.1056/NEJMoa040446

133. Walsh TJ, Finberg RW, Arndt C, Hiemenz J, Schwartz C, Bodensteiner D, Pappas P, Seibel N, Greenberg RN, Dummer S, Schuster M, Holcenberg JS (1999) Liposomal amphotericin B for empirical therapy in patients with persistent fever and neutropenia. National Institute of Allergy and Infectious Diseases Mycoses Study Group. N Engl J Med 340(10):764-771. https://doi.org/10. 1056/NEJM199903113401004

Publisher's note Springer Nature remains neutral with regard to jurisdictional claims in published maps and institutional affiliations. 